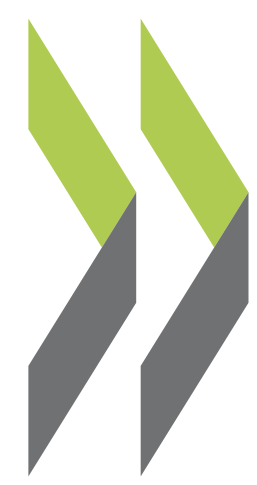

OECD Economics Department Working Papers No. 917

Employment Protection Legislation and Plant-Level Productivity in India
Sean Dougherty,

Verónica Frisancho Robles,

Kala Krishna 
Organisation de Coopération et de Développement Économiques

Organisation for Economic Co-operation and Development

16-Dec-2011

ECONOMICS DEPARTMENT

English - Or. English

EMPLOYMENT PROTECTION LEGISLATION AND PLANT-LEVEL PRODUCTIVITY IN INDIA ECONOMICS DEPARTMENT WORKING PAPER No. 917

By Sean Dougherty, Verónica Frisancho Robles \& Kala Krishna

Document only available as pdf.

All Economic Department Working Papers are available through the OECD internet website at www.oecd.org/eco/workingpapers

JT03313486

Document complet disponible sur OLIS dans son format d'origine

Complete document available on OLIS in its original format 


\section{ABSTRACT/RÉSUMÉ Employment Protection Legislation and Plant-Level Productivity in India}

Using plant-level data from the Annual Survey of Industries (ASI) for the fiscal years from 1998-99 through 2007-08, this study provides plant-level cross-state/time-series evidence of the impact of employment protection legislation (EPL) on total factor productivity (TFP) and labour productivity in India. Identification of the effect of EPL follows from a difference-in-differences estimator inspired by Rajan and Zingales (1998) that takes advantage of the state-level variation in labour regulation and heterogeneous industry characteristics. The fundamental identification assumption is that EPL is more likely to restrict firms operating in industries with higher labour intensity and/or higher sales volatility. Our results show that firms in labour intensive or more volatile industries benefited the most from labour reforms in their states. Our point estimates indicate that, on average, firms in labour intensive industries and in flexible labour markets have TFP residuals $14 \%$ higher than those registered for their counterparts in states with more stringent labour laws. However, no important differences are identified among plants in industries with low labour intensity when comparing states with high and low levels of EPL reform. Similarly, the TFP of plants in volatile industries and in states that experienced more pro-employer reforms is $11 \%$ higher than that of firms in volatile industries and in more restrictive states; however, the TFP residuals of plants in industries with low labour intensity are 11\% lower in high EPL reform states than in states with lower levels of EPL reform. In sum, the evidence presented here suggests that the high labour costs and rigidities imposed through Indian federal labour laws are lessened by labour market reforms at the state level.

JEL classification: D24, F16, J5, J8, K31.

Keywords: Labour regulation; state-level reforms; difference-in-differences; firm heterogeneity; total factor productivity.

$* * * * * * *$

\section{La législation sur la protection de l'emploi et la productivité des entreprises en Inde}

À l'aide de données au niveau des entreprises, tirées de l'enquête annuelle sur les industries (ASI) pour l'ensemble des exercices comptables entre 1998-99 et 2007-08, cette étude présente des séries chronologiques pour des États indiens mettant en lumière l'incidence de la législation sur la protection de l'emploi (LPE) sur la productivité totale des facteurs (PTF) et la productivité du travail dans les entreprises indiennes. L'incidence de la LPE est déterminée à partir d'un estimateur de la différence des différences inspiré de Rajan et Zingales (1998), qui tire parti des différences de réglementation au niveau des États et des caractéristiques hétérogènes des secteurs d'activité. L'hypothèse de base retenue pour la détermination de l'incidence est que la LPE est plus susceptible de peser sur les entreprises exerçant leurs activités dans un secteur à forte intensité de main-d'œuvre et/ou dont la volatilité des ventes est élevée. Nos résultats montrent que les entreprises relevant de secteurs à forte intensité de main-d'œuvre ou plus volatils sont celles qui ont le plus tiré profit des réformes du marché du travail mises en place dans leurs États. Nos évaluations de point indiquent qu'en moyenne, les entreprises de secteurs à forte intensité de main-d'œuvre et évoluant dans un marché du travail flexible affichent, pour la PTF, des chiffres résiduels supérieurs de $14 \%$ à ceux de leurs homologues implantées dans des États dont la législation sur le travail est plus stricte. Toutefois, aucun écart important n’a été décelé entre les entreprises de secteurs à faible intensité de main-d'œuvre lorsque l'on compare les États qui ont peu et beaucoup réformé leur LPE. De même, la PTF des entreprises de secteurs volatils implantées dans des États ayant imposé des réformes plus favorables aux employeurs est supérieure de $11 \%$ à celle des entreprises de secteurs volatils implantées dans des États plus restrictifs. Cependant, les chiffres résiduels de la PTF des entreprises exerçant leurs activités dans des secteurs à faible intensité de main-d'œuvre sont inférieurs de $11 \%$ dans les États ayant beaucoup réformé leur LPE par rapport à ceux qui ont peu réformé leur législation dans ce domaine. En conclusion, les éléments présentés ici donnent à penser que les effets des coûts élevés du travail et des rigidités imposées par la législation fédérale indienne sur l'emploi sont atténués par les réformes du marché du travail mises en œuvre au niveau des États.

Classification JEL : D24, F16, J5, J8, K31.

Mots-clefs : La réglementation du travail :, réformes au niveau des États ; différence des différences ; l'hétérogénéité des entreprises, productivité totale des facteurs.

Copyright OECD 2011.

Application for permission to reproduce or translate all, or part of, this material should be made to: Head of Publications Service, OECD, 2 rue André-Pascal, 75775 Paris CEDEX 16, France.

This document and any map included herein are without prejudice to the status of or sovereignty over any territory, to the delimitation of international frontiers and boundaries and to the name of any territory, city or area. 
$\mathrm{ECO} / \mathrm{WKP}(2011) 86$

\title{
EMPLOYMENT PROTECTION LEGISLATION AND PLANT-LEVEL PRODUCTIVITY IN INDIA
}

\author{
Sean Dougherty, Verónica Frisancho Robles, and Kala Krishna*
}

\section{Introduction}

It is well known that India's formal Employment Protection Legislation (EPL) is among the most stringent in the world. Many believe that this is one of the main reasons behind the stagnant share of manufacturing output in India's GDP during the last 40 years (OECD, 2007). Although the country has recorded impressive output growth rates since the 1970s, the share of manufactures in total output has remained between $14 \%$ and $18 \%$. Though infrastructure and product market regulation have been major challenges, strict labour laws have been blamed in particular for the poor performance of large-scale labour intensive manufactures despite India's labour abundance (Panagariya, 2008; Conway and Herd, 2009; Dougherty et al., 2009). According to the Indian Ministry of Commerce and Industry (2011), the top five goods exported during 2010-11 represented almost $50 \%$ of the country's total exports and they were all relatively capital intensive goods such as petroleum products, gems and jewelry, transport equipment, machinery and instruments, and pharmaceutical products. In contrast, ready-made garments, traditionally an unskilled-labour intensive export, has seen its share in total Indian exports decline from $12.5 \%$ to $6 \%$ between 2000 and 2010. In 2009, India was the fifth largest exporter of apparel with $3.6 \%$ of the world's exports (WTO, 2010).

Industrial relations in India fall under the joint jurisdiction of central and state governments, an arrangement that has generated a degree of variation in labour regulations across states. Although all states had essentially the same starting point under the License Raj, each state has independently

\footnotetext{
*Sean Dougherty is Senior Economist in the OECD Economics Department. Verónica Frisancho Robles is a $\mathrm{PhD}$ candidate at The Pennsylvania State University. Kala Krishna is Professor of Economics at The Pennsylvania State University and Research Associate at the NBER. The corresponding author is Sean Dougherty, Email: Sean.DOUGHERTY@oecd.org. We would like to thank TCA Anant (Ministry of Statistics) and Alok Sheel (Ministry of Finance) for their support of this project, which was partially carried out while Sean Dougherty was visiting the National Institute of Public Finance and Policy (New Delhi) and Verónica Frisancho Robles was an external consultant to the OECD. Useful feedback was received from colleagues at the OECD (notably Orsetta Causa, Romain Duval, Robert Ford and Sam Hill), The Pennsylvania State University and the Paris School of Economics. The views expressed in this paper are those of the authors and do not necessarily reflect those of the NBER, the OECD nor its member countries or partners.
} 
amended labour regulations, rules and practices during the post-Independence period. In the last decade, this "natural experiment" setting has been exploited by several empirical studies that have tried to assess the effects of labour regulation on output, employment, and productivity 1 However, and despite increasing interest in the topic, the evidence for India is still inconclusive and mostly limited to industry-level analysis.

One of the most influential studies of India is Besley and Burgess (2004), which constructs an index summarizing state-level amendments to the Industrial Disputes Act (IDA) between 1949 and 1992. The index, henceforth referred to as BB, is used along with several control variables to explain state-level outcomes corresponding to the organized manufacturing sector using industrylevel panel data for 1958-92. The authors identify a negative impact of pro-worker regulation on output, investment, employment, and labour productivity among registered manufacturing firms. Several papers that also rely on the BB index reach similar conclusions 2

Nonetheless, the validity of the BB index and the econometric methodology used to identify the effect of excessive pro-worker regulation have been extensively criticized. The main concerns with the use of this index are related to problems in the coding of labour laws and its exclusive focus on formal reforms to the IDA. This study tries to overcome the shortcomings of the previous empirical evidence in the tradition of Besley and Burgess (2004) to evaluate the effect of labour regulation on the Indian organized manufacturing sector. We make use of a more comprehensive measure of labour market regulations proposed in OECD (2007) and elaborated in Dougherty (2009). We argue that this index is superior to the BB index as it includes information on formal and informal labour market reforms, not only to the IDA but in seven additional areas: the Factories Act, the State Shops and Commercial Establishments Acts, the Contract labour Act, the role of inspectors, the maintenance of registers, the filing of returns and union representation.

Using this comprehensive EPL measure and plant-level data from the Annual Survey of Industries (ASI) for all the fiscal years between 1998-99 and 2007-08, we evaluate whether labour market regulation differences across Indian states led to a differential response in industrial performance 3 However, differences across states in terms of labour regulation may be endogenous. A higher number of pro-employer reforms in a given state may be driven by the characteristics of the firms

\footnotetext{
${ }^{1}$ One must keep in mind that the state-level amendments may not have been as exogenous as a true natural experiment would require.

${ }^{2}$ See Aghion et al. (2008) and Ahsan and Pagés (2006) as examples.

${ }^{3}$ In this paper, EPL is used as a shorthand to refer to a customized measure of state-level labour regulation reforms in India as presented in OECD (2007) and elaborated in Dougherty (2009). The official OECD measure is country-specific and has a longstanding standardized definition, as most recently elaborated in Venn (2009).
} 
located in that state.

Following Rajan and Zingales (1998), we focus on the details of the theoretical mechanisms at play. As we will show below, unit labour costs increase with more stringent EPL, and more so for firms operating in industries with higher labour intensity. This implies that firms in industries with higher labour shares will suffer the most from the additional costs of hiring and firing workers. Thus, we implement a difference-in-difference estimator that exploits both the variation in EPL by state, as well as the variation in industry-specific characteristics related to labour intensity and volatility. In addition, to the extent that such costs act as adjustment costs, they will have more of an effect in more volatile industries so that the productivity of firms in more volatile sectors should be more affected by strict labour laws. By focusing on a specific mechanism through which EPL reform operates (labour intensity or volatility), this approach provides stronger evidence of causality.

Previous studies have also exploited the variation in state and industry characteristic 4 but their focus was at the industry level. To our knowledge, this is the first study of India to evaluate the effect of labour regulation on plant-level productivity using a longitudinal sample 5 and is one of only a few studies on any country to examine labour regulation effects at the plant level.

The evidence presented here shows that firms in industries with higher labour intensity or higher sales volatility benefited the most from labour market reforms in their states. The positive effect of relaxed EPL on organized manufacturing firms in labour intensive industries is experienced through higher total factor productivity (TFP) although there is no consistent effect on labour productivity measured as value added per worker. Similarly, firms in more volatile industries that experience pro-employer labour reforms tend to have higher levels of TFP. We also identify a heterogeneous effect of EPL in labour intensive industries by plant size and ownership type. In particular, we find that smaller firms and private firms with a high usage of labour inputs tend to benefit the most from relaxation of state labour laws. In general, our results suggest that state-level reforms can help to mitigate the detrimental effects that strict federal labour laws have on industrial outcomes in the organized Indian manufacturing sector.

Our paper contributes to two strands of literature. First, its adds to the literature that focuses on the effect of labour and product regulation on industrial outcomes and economic performance, of which Besley and Burgess (2004) has been one of the most influential studies. It also contributes

\footnotetext{
${ }^{4}$ See Gupta et al. (2009) and Bassanini et al. (2009).

${ }^{5}$ Harrison et al. (2011) use a similar dataset also based on the Annual Survey of Industries (ASI) to examine market share reallocations; however they focus on trade policy reforms.
} 
to some recent studies on the potential links between labour markets and comparative advantage that have received special attention in the trade literature. Within this literature, our study is particularly related to Cuñat and Melitz (2007) and Krishna and Levchenko (2009), who highlight the role of firm-level volatility in determining the pattern of comparative advantage.

The rest of the paper proceeds as follows. Section 2 sketches out the major findings in the literature. Section 3 describes the data as well as some basic stylized facts. The empirical strategy is described in Section 4 while Section 5 displays the results. Some robustness checks are presented in Section 6. Section 7 concludes and describes the limitations of the study, as well as directions for future research.

\section{Previous Literature}

Despite increasing interest in the effect of institutions and regulation in industrial performance, the theoretical and empirical evidence to support or negate the beneficial effect of EPL relaxation is still limited. Although labour market equilibrium models such as Garibaldi's (1998) and Mortensen and Pissarides's (1999) predict a negative effect of stricter EPL on job mobility, its effects on productivity are not that straightforward.

Stricter labour regulation increases the costs of hiring and firing workers, making it more difficult for the firm to react to demand or supply shocks that require labour reallocation or staff reduction. The restriction of labour movement even in more productive firms or sectors can thus result in lower productivity levels. Poschke (2009) develops a model that takes into account firm dynamics and where firms receive idiosyncratic productivity shocks. He shows that selection eliminates the active firms with the lowest productivity, and entrants imitate more productive survivors. In this setting, strict EPL ends up reducing firm value, discouraging not only entry but also the exit of less productive firms. Moreover, growth losses tend to be larger when productivity is more volatile. This latter result is in line with previous findings of worse effects of strict EPL for firms operating in more turbulent sectors (see Bentolila and Bertola, 1990).

Negative effects of EPL on productivity can also be expected to act through lower worker efforts due to a lower threat of getting fired. Product or technology innovation can also be discouraged if the firm has to face high labour costs and high layoff costs in case of failure.

Another branch of the literature suggests that the net effects of EPL on productivity may be positive. Workers may be more willing to invest in human capital specific to the firm if their jobs are better protected. Firms may also be willing to invest more to increase labour productivity 
as an alternative to downsizing. Bassanini et al. (2009) provide an extensive discussion of these theoretical results suggesting that there might be an "optimal" level of EPL.

A recent paper by Cunat and Melitz (2007) studies the link between volatility, labour market flexibility, and international trade. They develop a model and test it using country-industry level data and find that countries with more flexible labour markets fare better in more volatile industries, where their ability to adjust to unexpected shocks is more important. This implies that labour market reforms might have differential effects across industries and that their effects might be more beneficial among sectors with a higher dispersion of within-industry shocks.

The empirical literature available is quite inconclusive and has tried to measure the effects of EPL on industrial outcomes using cross-country studies with industry-level data or industrystate-level data. Among the first group of papers, Micco and Pagés (2007) implement a differencein-differences estimator in a cross-section of industry-level data for a sample of developed and developing countries. They are able to identify the effect of EPL by arguing that sector differences in the intrinsic volatility of demand and supply shocks can lead to differential responses to labour regulation. Their results show that EPL reduces turnover, employment, and value added in more volatile industries but they only find weak evidence of a negative relationship between labour regulation stringency and labour productivity. Similarly, Bassanini et al. (2009) use aggregate cross-country/time-series data on OECD countries to measure the differential effects of countrylevel EPL on industry-level productivity. They find that dismissal regulations tend to generate larger TFP growth loses among industries with a high layoff propensity relative to industries where firms rely less on layoffs to adjust labour-inputs' usage.

A recent strand in the empirical literature focuses on India, one of the countries with the strictest labour regulation in the world. Although Indian labour laws were strongly influenced by the British model inherited on independence, it is clear that Indian labour regulation is substantially more protective than the UK's present system, as shown in Figure 1] The gap between these countries broadens after 1979, which is when a conservative government committed to labour market deregulation was elected in the UK. India fares even worse when compared to the US. However, the Indian case is particularly interesting and a nice setting for empirical studies given the ability of state governments to introduce formal and informal amendments to the labour laws. Consequently, changes in the application of the law at the state-level have resulted in important variations in the stringency of EPL within the same country.

First promoted by Besley and Burgess (2004), most studies focusing on India tend to use cross- 
Figure 1: Evolution of Labour Law in India, UK, and the US

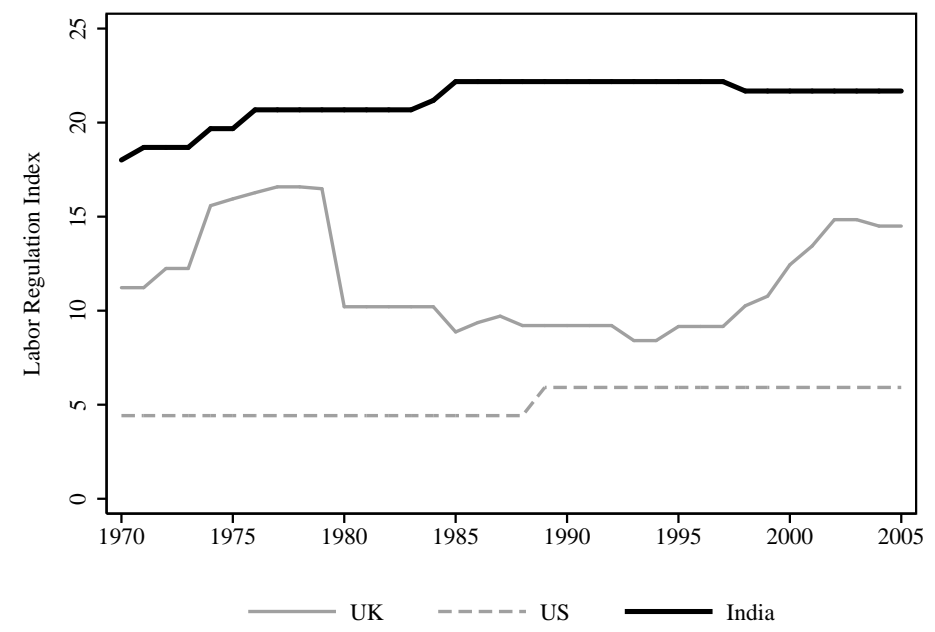

Source: Deakin, Simon, Priya Lele, and Mathias Siems. 2007. "The Evolution of Labour Law: Calibrating and Comparing Regulatory Regimes", International Labour Review, 146: 133-162.

Notes: The laws reported for India are mostly federal laws. The authors also report some state-level variations in case law, especially for the most heavily industrialized states. The labour regulation index is a score obtained out of 40 possible points, where higher values indicate more stringent regulation.

state and intertemporal variation in labour legislation as measured by state IDA amendments. These studies find that changes towards more flexible labour regulation are correlated with higher levels of manufacturing output, employment, and labour productivity in the organized industrial sector. For example, Aghion et al. (2006) find that, following delicensing, industries located in states with pro-employer labour regulations grew more quickly than those in pro-worker environments. Ahsan and Pagés (2009) also use the BB index but decompose it into amendments that reduce transaction costs of initiating and sustaining industrial disputes and those that increase job security and reduce labour flexibility. Their results suggest that regulations that increase the cost of settling disputes are more costly for employment than the restrictions directly imposed by the IDA.

Focusing on rural India, Adhvaryu et al. (2009) develop a partial equilibrium model where agriculture exists alongside industry. They use use rainfall fluctuations to measure exogenous unobserved demand and cost shocks, and analyze the response of states with different labour regulations as measured by the $\mathrm{BB}$ index. Their results show that the change in employment is significantly greater in states with laxer labour laws. However, shocks do not generate a differential response in output or profits. This is explained by a greater adjustment of the use of capital and 
materials in pro-worker states.

Despite its extended use in the empirical literature, the BB index has been heavily criticized. Bhattacharjea (2006, 2009) claims that the Besley and Burgess (2004) scoring system can erroneously classify a state as pro-employer or pro-worker with just one or two amendments to the IDA in the 50 years covered by the index. Nagaraj (2004) points out that the BB index focuses only on the IDA, abstracting from several other labour laws that affect industrial performance. Another important critique is its exclusive focus on formal amendments, which ignores changes in the actual practices and enforcement of the labour laws. In fact, most recent changes in state-level practices have resulted from judicial interpretations of the laws by the Supreme Court. It is thus not surprising updates of the BB index, using Malik (2006), show very few changes in labour regulation after 1992. Bhattacharjea (2006, 2009) also emphasizes the fragility of Besley and Burgess' (2004) econometric results. In particular, he criticizes the use of irrelevant state-level control variables and inadequate tests for robustness as well as the fragility of their results once state-specific time trends are introduced in their model.

A recent study by Gupta et al. (2009) tries to overcome some of the BB index's measurement problems by using a simple majority rule across three EPL measures available in the empirical literature, including the BB index. They argue that this approach has the advantage of weeding out any measurement error, unless there are systematic mistakes in coding the states across different indicators. Using this state-level composite measure of EPL, they exploit industry-level variation in labour usage to test the differential impact of product and labour market regulations. They find that labour intensive industries in states with flexible labour regulation have higher levels of value added.

Bhattacharjea (2009) departs from Besley and Burgess' (2004) work by focusing on the legislative content of the state-level amendments as well as on the judicial interpretations to Chapter V of the IDA 6 Although his proposed index is better in the sense that it includes information on practices at the ground level, he still focuses on only one labour law. His results on the effect of state-level labour regulation reform on the number of factories, value added, and share of contract labour are mixed but he highlights that his main contribution lies on his critique of the earlier literature.

All in all, the evidence on the effects of EPL on TFP and/or TFP growth in India is still scarce.

\footnotetext{
${ }^{6}$ This chapter relates to firms' requirements to obtain government permission for layoffs, retrenchments, and closures.
} 
This gap in the literature is even larger when we focus on the evidence available at the plant or firm level. Besides the well known difficulties involved in TFP estimation at the plant level, the fact that state-level changes in the labour regulation may be endogenously determined requires additional sources of variation in the data to identify the effect of EPL on plant-level productivity.

In particular, we expect labour regulation differences to have heterogenous effects on productivity across industries with different levels of labour intensity. Assuming there is a Cobb-Douglas production function specific to each manufacturing industry, $Y=A L^{\alpha} K^{1-\alpha}$, the unit cost function (which is inversely related to $A$, multifactor productivity) will be given by:

$$
c=\frac{1}{A}\left(\frac{w R_{s}}{\alpha}\right)^{\alpha}\left(\frac{r}{1-\alpha}\right)^{1-\alpha}
$$

where $w$ and $r$ are the labour and capital input prices. Employment protection legislation is captured through the constant $R_{s}$ which multiplies wages in state $s$ to capture the effective cost of labour. Whenever labour legislation imposes additional costs through layoff regulation or hiring restrictions, $R_{s}$ will be above 1 .

The percentage change in the unit cost with respect to $R_{s}$ will be given by:

$$
\frac{\partial \log c}{\partial R_{s}}=\frac{\alpha}{R_{s}}
$$

which is positive and increasing in $\alpha$. In other words, the percentage change in the unit cost is higher as EPL becomes stricter and more so for labour intensive industries. Our study will then identify the effect of EPL by taking advantage of the state-level variation in labour regulation as well as the industry-level variation in labour intensity as measured by an estimate of $\alpha$.

\section{Data}

The data used in this study comes from the Indian Annual Survey of Industries (ASI), conducted by the Indian Ministry of Statistics (MOSPI). We use ASI data from the 1998-99 through 2007-08 fiscal years to obtain an unbalanced panel of registered manufacturing plants. Previous studies using the same data source have been unable to build a plant-level panel due to the lack of factory identifiers that have only been made available recently 7 We differ from virtually all of them in that we make use of a subsample of plants that constitute a panel 8

\footnotetext{
${ }^{7}$ We thank India's Central Statistical Organisation (CSO) for providing us the data we use for this study. The confidentiality of the unit level data was maintained and adequate precautions have been taken to avoid disclosing the identity of the units directly or indirectly.

${ }^{8}$ A notable exception is Harrison et al. (2011), which uses the ASI panel to examine the role of market-share reallocations in aggregate productivity growth in India's organized manufacturing sector between 1985 and 2004.
} 
The ASI sampling frame includes all factories employing 10 or more workers using power, or 20 or more workers without using power. In general, the ASI's basic strategy over the years has been to divide the survey frame into census and sample sectors, where the census sector includes larger plants. Although this strategy has remained intact, the definition of census and sample sectors has undergone some changes over the years. Between the 1998-1999 and 2007-2008 rounds, the size threshold for the census sector fluctuated between 50 and 200 workers, so that only plants employing 200 or more workers are always surveyed during the years analyzed 9 The remaining plants are randomly sampled. For more details about the sampling design changes as well as a detailed description of the data problems present in ASI see Bollard et al. (2010); Harrison et al. (2011) discuss the new longitudinal sample.

ASI data provides factory reports on output, value added, fixed capital, investment, materials, fuel, labour, and labour expenditures. It also provides information on the type of ownership, the type of organization, as well as the start-up year of each plant. The ASI reports the book value of fixed capital both at the beginning and at the end of the fiscal year, net of depreciation. Our measure of fixed capital will be the average of the net book value of fixed capital at the beginning and at the end of the fiscal year, while all other variables are measured at the end. The data collected from the ASI are at current prices and must be corrected for price changes over time. Details on the specific deflators used for each variable can be found in Appendix A.

The raw data consist of about 384,000 observations over 10 years, with an average of about 38,000 plants surveyed each year. We remove observations corresponding to non-operative plants $(26,553)$ and plants with non-positive values of output and negative values of fixed capital stock (499). Table 1 shows that following this, on average, $26 \%$ of the observations in each round have missing values for output, value added, materials, fuels, fixed capital, or labour. After removing these observations, we also drop 3 manufacturing industries (2-digit NIC) with too few observations: other mining and quarrying, recycling, and office, accounting, and communication equipment. Following Aghion et al. (2008) and Gupta et al. (2009), we also drop "other" manufacturing industries. This category groups different activities which are likely to vary across states, making it incomparable across states. Finally, we also drop the states and union territories of Jammu \& Kashmir, Chandigarh, Nagaland, Manipur, Tripura, Meghalaya, Daman \& Diu, Dadra \& Nagar Haveli, Pondicherry, and Andaman \& Nicobar Islands due to lack of information on employment legisla-

\footnotetext{
${ }^{9}$ All industrial units belonging to the five least industrially developed states (Manipur, Meghalaya, Nagaland, Tripura and Andaman \& Nicobar Islands) were also included in the census sector.
} 
Table 1: Percentage of missing observations in each ASI round

\begin{tabular}{lrrr} 
Year & Total Obs. $^{a /}$ & Missing Obs $^{b /}$ & \% Missing \\
\hline $1998-1999$ & 23,620 & 4,290 & 18.2 \\
$1999-2000$ & 24,684 & 6,944 & 28.1 \\
$2000-2001$ & 31,053 & 8,349 & 26.9 \\
$2001-2002$ & 33,387 & 8,579 & 25.7 \\
$2002-2003$ & 33,800 & 8,625 & 25.5 \\
$2003-2004$ & 45,429 & 12,483 & 27.5 \\
$2004-2005$ & 39,714 & 11,503 & 29.0 \\
$2005-2006$ & 43,675 & 10,039 & 23.0 \\
$2006-2007$ & 43,304 & 12,812 & 29.6 \\
$2007-2008$ & 38,439 & 10,777 & 28.0 \\
\multicolumn{4}{|}{} \\
Total & 357,105 & 94,401 & 26.4 \\
\hline \multicolumn{4}{c}{ After removal of non-operative plants and plants with non- } \\
positive values of output and fixed capital stock. Only 7\% of all \\
observations are dropped for these reasons. \\
$b /$ Observations are coded as missing when the factory does not \\
have data on output, value added, materials, fuels, fixed capital, \\
labour, or labour expenditures.
\end{tabular}

tion. We also exclude Lakshadweep due to lack of data in the ASI and Goa given its economy's dependence on tourism.

The final sample consists of 239,921 plant-year observations with data on 103,478 plants in 20 states. Almost $60 \%$ of the observations and $74 \%$ of the plants in our data come from the sample sector. Moreover, almost $50 \%$ of the plants appear in only one round of the survey. As expected, these are smaller plants, with an average of 48 workers. This is an important limitation of the ASI; since plants in the sample sector are not deliberately followed over time, entry and exit for smaller plants is missed. Due to changes in the census threshold size, exit and entry is only consistently observed for census plants with at least 200 workers. We call this sample the restricted census sample which contains 49,895 plant-year observations on 11,343 plants. Basic statistics on the final sample are presented in Table B.1 in Appendix B.

We rely on the restricted census sample to obtain TFP estimates but use information on all the plants surveyed to measure the effect of EPL on productivity. To take into account simultaneity and selection biases, we obtain production function estimates using the Olley-Pakes estimator. Since this approach uses information on plants' exits and lagged values of some variables, we only apply it to the restricted census sample. We then apply estimates of the production function's parameters to the full sample of plants and obtain TFP residuals for all plants in ASI's census and sample sectors. 
An additional problem posed by ASI data is the substantial number of outliers. To reduce their influence in our estimates, we "winsorized" the data, following Bollard et al. (2010). This procedure basically implies top-coding and bottom-coding the $1 \%$ tails for each plant-level variable. In other words, for each year and each variable we replace outliers in the top $1 \%$ tail (bottom 1\% tail) with the value of the $99^{\text {th }}\left(1^{\text {st }}\right)$ percentile of that variable. This procedure was applied separately to each 2-digit industry 10

Our measure of labour reform comes from the OECD index which summarizes state-level indicators of procedural changes to the implementation of labour laws either through formal amendments or through de facto practices (Dougherty, 2009). The OECD, with the support of the All-India Association of Employers (AIOE), surveyed 21 Indian states in 2007. The EPL index reflects the extent to which procedural or administrative changes have reduced transaction costs in relation to labour issues. It is constructed using data from a survey instrument developed to identify areas in which Indian states have experienced specific changes to the implementation and administration of labour laws. The survey covered 50 specific subjects of possible reform in 7 major areas of labour regulation in addition to the IDA: the Factories Act, the State Shops and Commercial Establishments Acts, the Contract Labour Act, the role of inspectors, the maintenance of registers, the filing of returns and union representation. We use the ordinal EPL count index, rebased and rescalled from zero to one, which is essentially the p of areas in which pro-employer labour reform occurred. It is worth emphasizing that, although the OECD index can be separated by its subcomponents, we rely on the aggregate measure of labour reform since the index was designed to capture a state's general stance towards labour regulations more than the character of specific reforms.

To add state-level controls to our estimates, we gathered time series data on population, telephone availability, installed electric capacity, and paved road length. State population comes from census population data for 1991, 2001, and 2011, and it is linearly interpolated for other years. Time series data on fixed and mobile phones per 100 population comes from the Ministry of Statistics and Programme Implementation's (MOSPI) website. Installed electric capacity, measured as kilowatts per million people on the state, is obtained from the Annual Report of the Indian Ministry of Power for the years 1997-98, 2000-01, 2001-02, 2002-03, 2003-04, 2004-05, 2005-06, and 2007-08. State-wise surfaced road length is obtained from two sources: i) the Basic Road Statistics of India report from the Ministry of Road Transport and Highways for the years 2004-05, 2005-06, 2006-07,

\footnotetext{
${ }^{10}$ We do not remove these outliers because we would have generated an additional loss of 59,896 observations, about $25 \%$ of the complete sample.
} 
and 2007-08, and ii) the Planning Commission's 9th and 10th Five Year Plans. Road density is measured as paved kilometers per thousand people in the state.

We also include an OECD measure of state-level product market regulation as a time-invariant control to take into account the potential role of product regulation as a complement (or substitute) of labour market laws. The product market regulation index is taken from Conway and Herd (2008) and it contains information on state intervention and legal or administrative barriers to entrepreneurship.

In our robustness checks, we will also make use of the BB index that we update through 2008 using Malik (2010) as well as Gupta et al.'s (2009) labour market regulation composite index. The latter is based on a simple majority rule across the EPL indicators proposed in Besley and Burgess (2004), Bhattacharjea (2006), and Dougherty (2009). States are coded as pro-labour, pro-business, or neutral if the majority of the studies considered classified them as such. Additionally, we check the robustness of our results using industry-level layoff propensity instead of the measure of labour intensity captured by the estimated $\alpha s$. Layoff propensities are measured for the US between 2002 and 2003 with data from the 2004 CPS Displaced Workers Supplement (see Table A.3 in Bassanini et al., 2009) 11 Using these propensities, we construct a dummy variable for above and below the median industry.

We must emphasize that the ASI only provides data on organized manufacturing plants. In a country where the informal sector constitutes a majority of the labour force and the unorganized sector produces a third of total manufacturing value added, there is also a need to understand how EPL reforms have affected unorganized plants. A source of data on these plants is the National Sample Survey Organization's (NSSO) survey but it is only carried out every five years. This lack of data comparable to the ASI forces most researchers to focus exclusively on the registered, or organized sector. However, this focus is also appropriate since labour market rigidities in the organized sector constrain the absorption of formal workers, who tend to be more productive, receive higher wages, and face better working conditions than workers in the informal sector (Gupta et al., 2009). Moreover, Goldar and Aggarwal (2010) provide some evidence on the effects of labour market reforms in the unorganized manufacturing sector. Using the OECD labour market reform index for Indian states, they find a negative and significant relationship between labour laws' flexibility and the probability of being a casual worker both in the formal and informal manufacturing sector,

\footnotetext{
${ }^{11}$ The industry classification in this data (ISIC Rev. 3) does not exactly match the 2-digit industry classification of the ASI, so in some cases we had to merge Indian industries to make them comparable to those in the United States.
} 
$\mathrm{ECO} / \mathrm{WKP}(2011) 86$

although the effect in the organized sector is far stronger.

\subsection{Basic Patterns}

Using the OECD index, we classified states as having flexible EPL when they were above the median state according to the degree of labour regulation reforms carried out. Figure 2 plots the cumulative distribution of output and employment by labour laws' rigidity. Panel (a) suggests that the variation in labour standards across states may have allowed some states to fare better than others; the distribution of output in states with flexible labour laws first order dominates that of states with more stringent regulation. However, panel (b) of Figure 2 suggests that EPL does not seem to influence formal employment. Although these patterns are suggestive, we need to control for the states' total population to get a better idea of the general picture.

Figure 3 plots output and employment per capita at the state level in 2000 against our EPL reform indicator 12 Each observation in the scatter plot represents a state. Even after controlling for the state's population, Panel (a) in Figure 3 shows that there is a modest positive relationship between output per capita and the preponderance of labour law reforms in the state. However, this pattern is much weaker for formal employment per capita as shown in panel (b).

Figure 2: Output, employment, and EPL in 2000

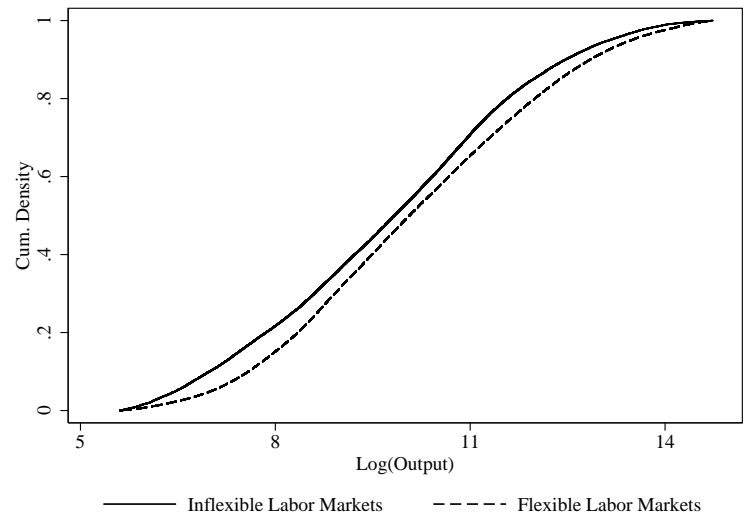

(a) Output

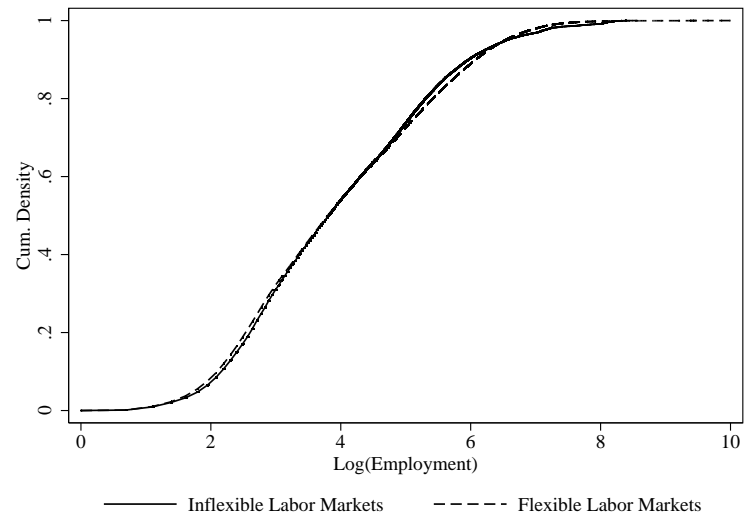

(b) Employment

Source: Annual Survey of Industries (ASI) 1998-99 to 2007-08 rounds.

\footnotetext{
${ }^{12}$ The OECD labour reform index has been re-scaled so that 0 corresponds to the lowest level of reform and 1 indicates the highest level of reform at the state level.
} 
Figure 3: Output and employment per capita and EPL in 2000

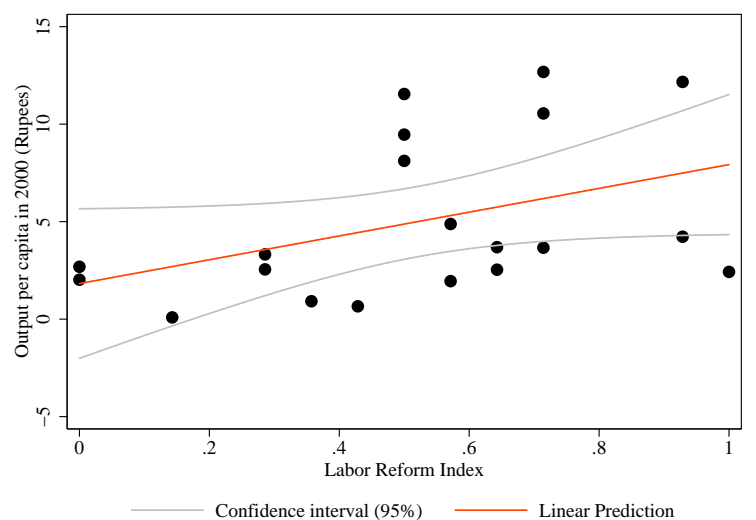

(a) Output

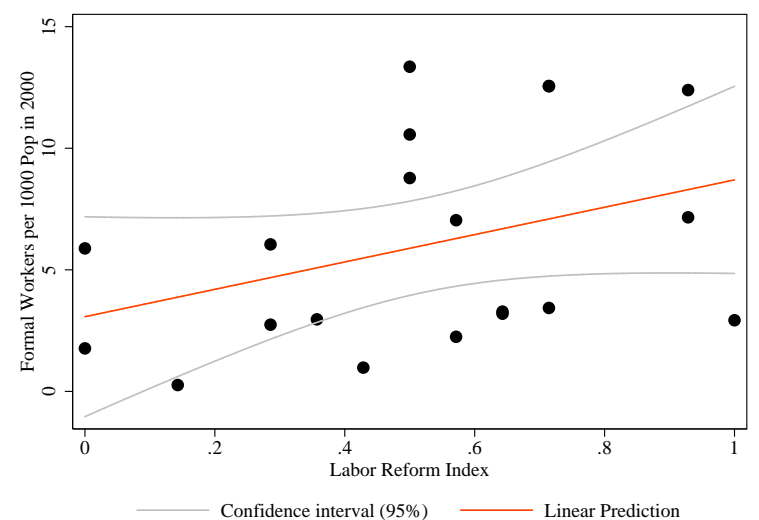

(b) Employment

Source: Annual Survey of Industries (ASI) 1998-99 to 2007-08 rounds.

However, differences in the number of plants in each state may be driving these patterns. To deal with this, Figure 4 decomposes total output and employment by EPL flexibility into their extensive and intensive margins. While the extensive margin is captured by the number of plants $(N)$, the intensive margin is measured by the average output or average employment per plant $(Q / N$ or $L / N)$. Both in terms of output and employment, states with more flexible regulation fare better than plants operating in more restrictive labour markets. However, most of this "advantage" seems to be explained by the evolution of the extensive margin. On average, intensive margin differences explain about $36 \%$ of the output gap and $9 \%$ of the employment differences between flexible and inflexible states 13

\footnotetext{
${ }^{13}$ Let the subscripts 0 and 1 correspond to outcomes in inflexible and flexible labour markets, respectively. Output differences can be decomposed in the following way:

$$
\left(\frac{Q}{N}\right)_{1} N_{1}-\left(\frac{Q}{N}\right)_{0} N_{0}=\left[\left(\frac{Q}{N}\right)_{1}-\left(\frac{Q}{N}\right)_{0}\right] N_{1}+\left(\frac{Q}{N}\right)_{0}\left[N_{1}-N_{0}\right]
$$

where the first term in the right hand side captures output differences coming from the intensive margin for a fixed number of plants. The second term fixes output per plant to capture extensive margin differences.
} 
Figure 4: Labour market regulations and manufacturing production and employment

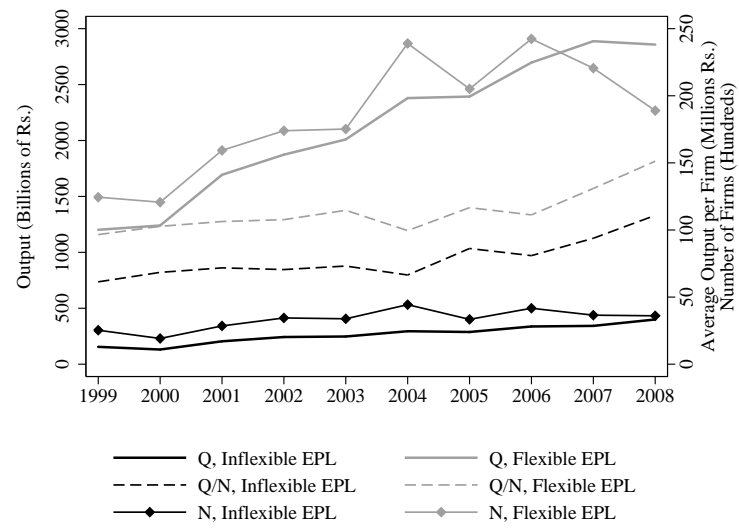

(a) Total output

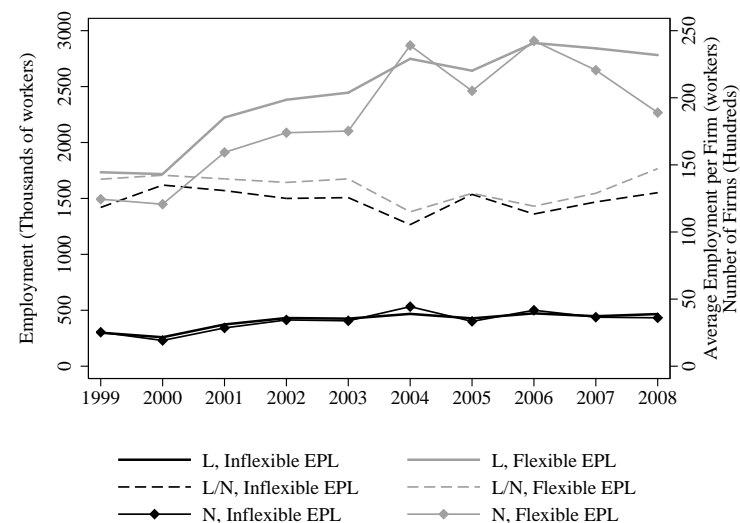

(b) Total employment

Source: Annual Survey of Industries (ASI) 1998-99 to 2007-08.

Figure 5 plots the distribution of TFP and labour productivity by EPL and labour intensity. We obtain TFP estimates separately for each industry (so that scaling is not an issue) using the OlleyPakes approach in the subsample of ongoing plants in ASI's panel. Sub-section 4.1 below describes the details of the estimation of TFP residuals, which yields unbiased estimates of the production function coefficients. In particular, we rely on the output elasticity with respect to labour, $\alpha$, estimated in the panel and identify labour intensive industries as those with an $\hat{\alpha}$ above the median industry. Following Besley and Burgess (2004), we also show labour productivity measured as value added per employee, net of industry fixed effects. Panels (a) and (b) show that industries with high labour intensity experience a greater improvement in their TFP distribution from the relaxation of labour laws' enforcement when compared to less labour intensive industries. Additionally, panels (c) and (d) show that, irrespective of the industry's labour usage, the distribution of labour productivity in flexible states is always to the right of that of states with stricter EPL but the distance between distributions is larger in labour intensive industries.

So far, this preliminary evidence suggests that labour intensive industries benefit the most from EPL relaxation in Indian states. Section 5 below will test if the patterns identified for productivity remain relevant after a more rigorous analysis. 
Figure 5: Labour market regulation, labour intensity, and productivity

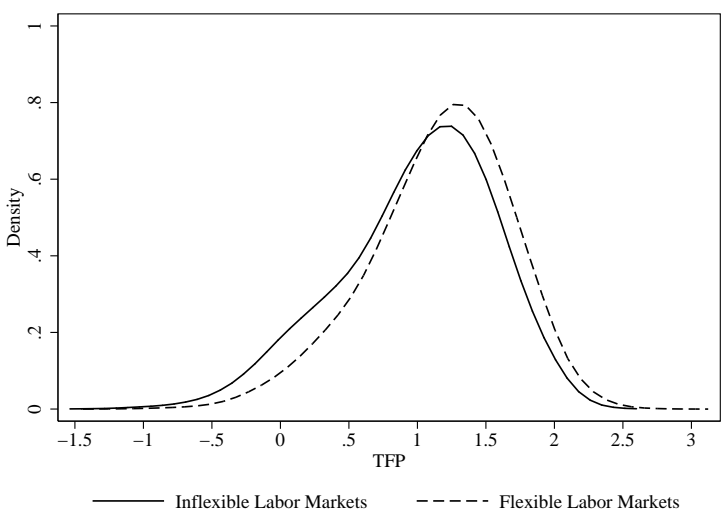

(a) TFP: High labour intensity

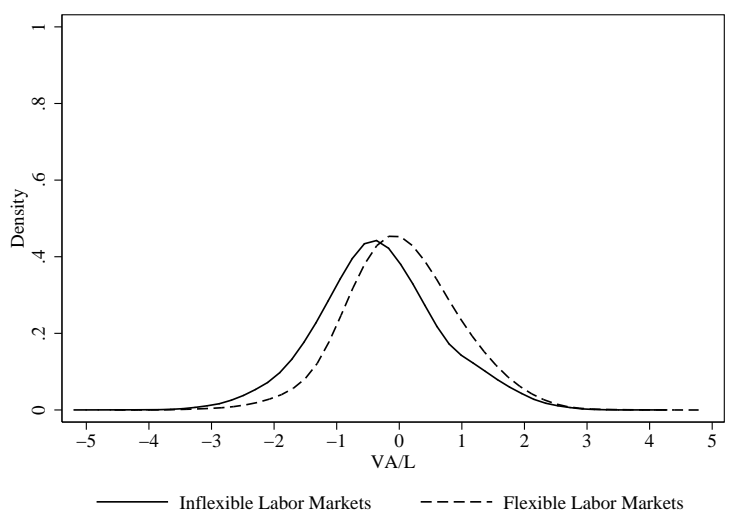

(c) Labor productivity: High labour intensity

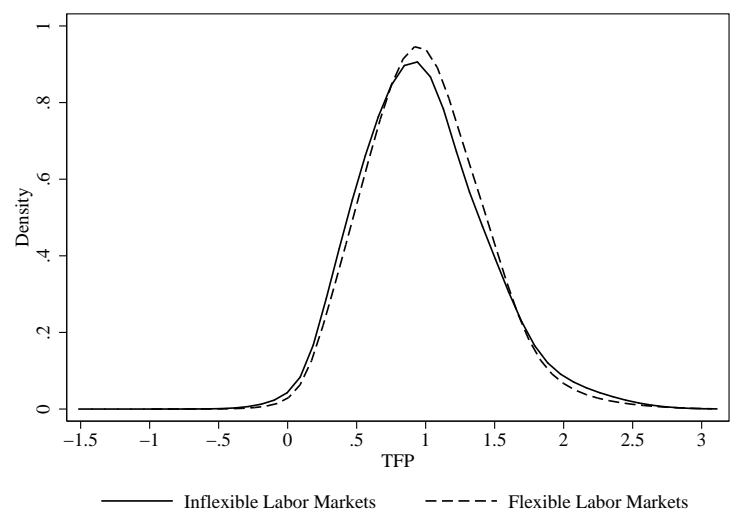

(b) TFP: Low labour intensity

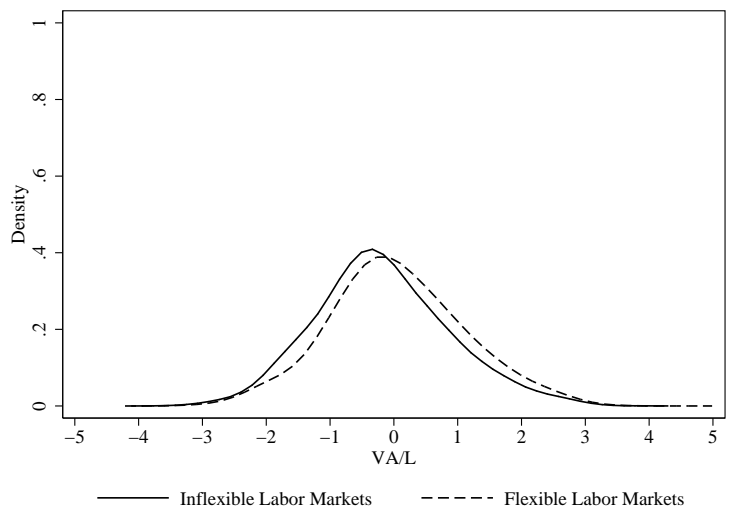

(d) Labor productivity: Low labour intensity

Source: Annual Survey of Industries (ASI) 1998-99 to 2007-08.

\section{Empirical Strategy}

The main objective of this study is to assess the effect of employment regulation reform in India on TFP and labour productivity between 1998-99 and 2007-08. The basic specification proposed to evaluate productivity performance is similar to the one used by Aghion et al. (2006), in the sense that we take advantage of state-level variation in labour regulation, but we extend it to incorporate industry-level variation. Our fundamental assumption is that EPL reform is more likely to restrict plants operating in industries with higher labour intensity, or alternatively higher volatility.

Consider the partial equilibrium effect of a change in EPL derived in (1). The impact on productivity is expected to be larger in industries where plants rely more on labour than in industries in which this input is relatively less important. We can also think of more volatile industries having 
a harder time adjusting their labour input usage when strict labour regulations are in place. To capture the effect of labour regulation reform, we use a difference-in-differences estimator inspired by Rajan and Zingales (1998). By comparing cross-industry differences in states with different levels of labour reform we can evaluate the effect of EPL changes towards pro-employer legislation on productivity levels. Labour intensive industries will be more constrained by labour regulation so the impact of EPL reform is identified using industries with a lower output elasticity with respect to output as a control group. Relaxation in labour regulation may also interact with industry-level differences in the dispersion of plant-level shocks to generate larger TFP gains among sectors with a higher dispersion of these shocks.

Below, we briefly describe the TFP estimates used in this study. Next, we proceed to describe the econometric model used to measure the impact of labour reform on manufacturing plants.

\subsection{TFP Measures}

When trying to estimate a production function using observed plant-level variables, obtaining TFP measures from the residuals encompasses several measurement and econometric problems. On one hand, measurement of outputs and inputs generates an aggregation problem, especially in multiproduct plants. Another measurement issue relates to capital usage; since it is very tough to obtain data on capital consumption as an input in the production process, the researcher has to settle for the book value of total capital and machinery involved in the production process.

Although the previous problems are complex enough, there is not much the empirical researcher can do about them but try to collect better quality and more detailed micro data. In addition to these problems, several econometric difficulties arise when estimating production functions at the plant level. Two of the most prominent and serious problems are simultaneity and selection biases.

Assume a Cobb-Douglas production function like the one described below:

$$
Y_{i t}=A_{i t} L_{i t}^{\alpha} K_{i t}^{\beta} M_{i t}^{\gamma} F_{i t}^{\lambda}
$$

where $Y_{i t}$ are physical units of output and $L_{i t}, K_{i t}, M_{i t}$, and $F_{i t}$ measure labour, fixed capital, materials, and fuels, respectively. Since $A_{i t}$ enters the right hand side in a multiplicative way, affecting all the other factors' marginal product simultaneously, it represents the TFP. Taking logarithms allows us to use a linear estimation model described by:

$$
y_{i t}=\alpha l_{i t}+\beta k_{i t}+\gamma m_{i t}+\lambda f_{i t}+u_{i t}
$$

where small letters are used for logs. 
From the estimation of equation (2), we can retrieve the error term $u_{i t}$, which is the $\log$ of plant-specific $A_{i t}$, provided that the coefficients on the inputs are consistently estimated. OLS estimation does not yield consistent estimates if plants' choices on exit and on factor demands (when they continue operating) depend on their productivity. This fact generates both a selection and a simultaneity problem in the estimation of production functions.

Olley-Pakes (1996) deals with the simultaneity problem by using the firm's investment decision to proxy for unobserved productivity shocks. It is assumed that a higher value of the productivity shock observed by the firm (but unobserved by us) will induce higher investment today. The OlleyPakes approach also offers a correction for selection bias due to exit. In the first stage, a probit of survival is estimated as a function of a polynomial of capital and investment and the fitted values from this regression are used in the second stage to consistently estimate the production function parameters 14

Since this technique requires information on exit and lagged values of some variables, we estimate the parameters in (2) using Olley-Pakes in the restricted census sample, for which panel data is available. We estimate the coefficients for capital, labour, materials, and fuels separately for each industry and assume that these estimates are applicable to plants in the census as well as in the sample sector. We can then obtain TFP as a residual for all the plants using the industry-specific coefficient estimates. Estimating TFP using industry-specific regressions allows for differences in the production function's coefficients, including a constant term, which yields unit-free productivity residuals that are comparable across industries. In the end, TFP residuals are obtained as the exponential of the residual in (2) 15

To estimate TFP at the plant level, we use real gross output instead of value added as the dependent variable. According to Basu and Fernald (1997) and Carlsson et al. (2011), the use of value added is only valid for TFP estimation under perfect competition and constant returns to scale 16 Labour is measured in number of workers and fixed capital is measured as the average of

\footnotetext{
${ }^{14}$ See Olley and Pakes (1996). Their approach assumes a strictly monotonic relationship between output and investment so that all observations with zero investment are dropped. An alternative approach to deal with the simultaneity bias is offered by Levinsohn and Petrin (2003), who use intermediate inputs as a proxy for investment to avoid losing observations. However, only $4 \%$ of the plant-year observations in the restricted census sample used to estimate TFP have zero investment. Moreover, unlike Olley-Pakes, Levinsohn-Petrin methodology does not offer a correction for selection bias. For more details on the problems faced when estimating productivity as well as available solutions, see Arnold (2005).

${ }^{15}$ Notice that since the error is mean zero, this explains why the mean of the TFP distribution in Figure 5 is so close to 1 .

${ }^{16}$ See Appendix C in Carlsson et al. (2011). They show that a residual measure of TFP that comes from value added is not independent of the use of intermediate inputs and factor input growth when there are increasing or decreasing returns to scale.
} 
the net book real value of fixed capital at the beginning and at the end of the fiscal year. The amount of fuels and materials consumed is used to measure the usage of these inputs. Investment is measured by the gross value of additions to fixed capital. All the variables are measured in rupees at the end of the period and in 1993-94 constant prices, unless otherwise noted.

\subsection{Econometric Model}

Our analysis of the impact of labour reform on manufacturing outcomes relies on this basic model:

$$
\log \left(W_{\text {fist }}\right)=\theta_{0}+\theta_{1} L I_{i}+\theta_{2} R_{s}+\theta_{3}\left(L I_{i} \times R_{s}\right)+\eta_{t}+\varepsilon_{\text {fist }}
$$

In equation (3), $W_{\text {fist }}$ is some performance outcome for plant $f$, in industry $i$ and state $s$, at year $t$. We analyze TFP and labour productivity (measured as value added per worker), but Appendix $\mathrm{B}$ also provides some evidence on total gross output and total value added. $L I_{i}$ denotes industry's $i$ labour intensity measure while state labour reform is captured by $R_{s}$.

Our indicator of $R_{s}$ is a dummy variable based on the normalized count of EPL reforms in each state. We label states as having flexible regulation when their labour reform index is at or above the median state in terms of the proportion of state-level reforms (using the count index). We adopt this dummy specification because the OECD measure of labour reform cannot be considered a continuous variable but is closer to an ordinal or categorical variable. However, there are too many categories to use it as such and the dummy specification eases presentation of the results.

To measure $L I_{i}$, we construct a dummy variable for above and below the median labour intensive industry based on the $\hat{\alpha}$ s obtained from the estimation of (2) 17 We believe that the use of $\hat{\alpha}$ to measure the intrinsic labour intensity in each industry is superior to the use of the share of labour expenditures in total output. The use of the estimated output elasticity with respect to labour overcomes the potential biases that the ratio of labour expenditures to output may have due to the endogeneity of the plant's input choices. Moreover, since our TFP estimation using Olley-Pakes' methodology takes into account year fixed effects, $\hat{\alpha}$ provides a clean estimate of the underlying labour intensity of each industry that is not biased by exogenous demand or supply shocks in the inputs markets.

An alternative specification of (3) uses industry volatility measures instead of labour intensity. In that case, we follow Krishna and Levchenko (2009) and measure industry volatility by the standard deviation of the annual growth rate of plants' output. We then construct a dummy variable for above and below the median volatile industry.

\footnotetext{
${ }^{17}$ Again, this specification follows the one of $R_{s}$ and facilitates the exposition of the results.
} 
Since our measure of EPL reform is time invariant and measured at the state level, we cannot include state fixed effects. Similarly, our labour intensity indicator is fixed at the industry level so it restrains us from including industry fixed effects 18 We control for year fixed effects, denoted by $\eta_{t}$ in equation (3), and add a plant-specific trend 19 Robust variance estimates are used to adjust standard deviations for within-state correlation. We also incorporate additional controls in our estimates to make sure we take into account the effect of state-level characteristics.

The coefficient $\theta_{3}$ on the interaction between $L I_{i}$ and $R_{s}$ will capture the heterogeneous effect of EPL reform on industries with different labour intensity. Given that $R_{s}$ is higher when state labour reforms make EPL more flexible, a positive coefficient on the interaction implies that plants in industries that use labour more intensively fare better in states with pro-employer labour regulation. In the alternative specification, which uses industry volatility measures instead of labour intensity, the interaction term should also have a positive coefficient since more volatile plants are expected to benefit the most from laxer labour regulations.

\section{Results}

The results presented in Table 2 provide initial evidence of a beneficial effect on multifactor and labour productivity for labour intensive industries in states with higher levels of pro-employer labour reform. The positive and significant interaction of $L I_{i}$ and $R_{s}$ in column 1 shows that manufacturing plants with high labour requirements that operate in states moving towards more flexible regulation exhibit larger TFP gains than plants in less labour intensive industries. The interaction in the value added per worker equation is also positive but it is not significant.

The point estimates from Table 2 imply that there are important multifactor productivity gains from conducting more labour reforms, particularly for plants in labour intensive industries. In 2008, the ratio of the geometric mean of TFP for plants in states with flexible labour markets over the geometric mean of TFP for plants in states with inflexible labour markets is 1.17 in labour intensive industries, but it is close to one in industries with lower $\hat{\alpha} s 20$ In other words, a plant in a labour intensive industry that moves from an inflexible to a flexible state would get an average

\footnotetext{
${ }^{18}$ Full collinearity restrains us from including industry-year, state-year, or industry-state fixed effects.

${ }^{19}$ Of course, this trend is only relevant for plants present in multiple years and its removal does not quantitatively or qualitatively affect the results.

${ }^{20}$ Using the parameter estimates from Table 2 the mean values of the trend, and the year dummy corresponding to 2008, we predict $\log$ (TFP) for 4 groups: i) plants in states with high levels of EPL reform and high $\hat{\alpha}$ s, ii) plants in states with low levels of EPL reform and high $\hat{\alpha}$, iii) plants with high levels of EPL reform and low $\hat{\alpha}$, and iv) plants with low levels of EPL reform and low $\hat{\alpha}$. To obtain 1.17, for example, we get the difference between the predictions of $\log (\mathrm{TFP})$ for group i) and ii) and exponentiate it to get the ratio of their TFP in levels.
} 
Table 2: Effect of EPL reforms on TFP and labour productivity by labour intensity

\begin{tabular}{lrr} 
& $\log (\mathrm{TFP})$ & $\log (\mathrm{VA} / \mathrm{L})$ \\
\hline Constant & $0.943^{* * *}$ & $-0.463^{* * *}$ \\
& $(0.031)$ & $(0.064)$ \\
High labour intensity & 0.016 & $-0.115^{*}$ \\
& $(0.051)$ & $(0.060)$ \\
Pro-employer EPL reform & 0.013 & $0.260^{* *}$ \\
& $(0.035)$ & $(0.109)$ \\
High labour intensity x Pro-employer EPL reform & $0.145^{* *}$ & 0.119 \\
& $(0.061)$ & $(0.079)$ \\
\hline Observations & 224,634 & 213,147 \\
R-squared & 0.043 & 0.043 \\
Firm trend & yes & yes \\
Year FE & yes & yes \\
\hline Source: Annual Survey of Industries (ASI) $1998-99$ to $2007-08$. & \\
Robust standard errors in parentheses. & & \\
${ }^{* * *} p<0.01,{ }^{* *} p<0.05,{ }^{*} p<0.1$ & &
\end{tabular}

TFP improvement of about $17 \%$ while TFP gains are close to zero in industries with lower labour intensity.

To check the robustness of our findings, we add a number of control variables to take into account state characteristics. These include both time-variant as well as time-invariant controls at the state level. Among the first group, we use the log of fixed and mobile phones's availability per 100 population, log of the installed electric capacity per million people, and the log of road density. Information on telephones, installed electric capacity, and road density are reasonable proxies for the general conditions of infrastructure, which are expected to be positively related to manufacturing output. We also include the OECD product market regulation index from Conway and Herd (2008) that measures how much regulations restrict competition.

Table 3 shows that the positive effect identified for labour intensive plants in flexible labour markets is still present for TFP once we control for state characteristics. The interaction between EPL reform and high labour intensity is positive and significant. Once state-level controls are introduced, our point estimates indicate that, on average, plants in labour intensive industries and operating in flexible labour markets have a TFP residual that is $14 \%$ higher than it is among plants in states with low levels of EPL reform and high $\hat{\alpha}$ s. Among plants in industries with low $\hat{\alpha}$, TFP gains from EPL reform are negligible. Although the interaction of EPL reform and labour intensity is not significant in the value added per worker equation, there are slightly larger gains among plants in labour intensive industries. While plants in industries with low $\hat{\alpha}$ s see their labour productivity increase by $28 \%$ where EPL reforms are more extended, the effect of EPL reform in 
$\operatorname{ECO} / \mathrm{WKP}(2011) 86$

labour intensive industries translates into VA/L increases of $45 \%$.

Table 3: Effect of EPL reforms on TFP and labour productivity by labour intensity, with state-level controls

\begin{tabular}{lrr} 
& $\log (\mathrm{TFP})$ & $\log (\mathrm{VA} / \mathrm{L})$ \\
\hline Constant & $1.274^{* * *}$ & -1.026 \\
& $(0.278)$ & $(1.012)$ \\
High labour intensity & 0.004 & $-0.118^{*}$ \\
& $(0.054)$ & $(0.062)$ \\
Pro-employer EPL reform & -0.023 & $0.248^{* *}$ \\
& $(0.044)$ & $(0.092)$ \\
High labour intensity x Pro-employer EPL reform & $0.153^{* *}$ & 0.124 \\
& $(0.063)$ & $(0.075)$ \\
Time-variant state controls & & \\
Log(Telephones/100 pop) & $0.043^{* *}$ & 0.031 \\
& $(0.019)$ & $(0.044)$ \\
Log(Installed electricity capacity/million pop) & -0.018 & 0.019 \\
& $(0.021)$ & $(0.115)$ \\
Log(Paved roads $/ 1000$ pop) & 0.014 & -0.027 \\
& $(0.014)$ & $(0.065)$ \\
Time-invariant state controls & & \\
Product Market Regulation & -0.032 & 0.060 \\
& $(0.050)$ & $(0.292)$ \\
\hline Observations & 224,634 & 213,147 \\
R-squared & 0.048 & 0.044 \\
Firm trend & yes & yes \\
State-level controls & yes & yes \\
Year FE & yes & yes \\
\hline Source: Annual Survey of Industries (ASI) 1998-99 to $2007-08$. & \\
Robust standard errors in parentheses. & & \\
${ }^{* * *} p<0.01,{ }^{* *} p<0.05,{ }^{*} p<0.1$ & & \\
& &
\end{tabular}

Next, we try to identify differential effects by plant size and type of ownership. Let $X_{\text {fist }}$ denote a specific plant characteristic, such as size or ownership type. We extend the model in (3) in the following way:

$$
\begin{aligned}
\log \left(W_{\text {fist }}\right) & =\theta_{0}+\theta_{1} L I_{i}+\theta_{2} R_{s}+\theta_{3}\left(L I_{i} \times R_{s}\right) \\
& +\theta_{4} X_{\text {fist }}+\theta_{5}\left(L I_{i} \times X_{\text {fist }}\right)+\theta_{6}\left(R_{s} \times X_{\text {fist }}\right)+\theta_{7}\left(L I_{i} \times R_{s} \times X_{\text {fist }}\right)+\eta_{t}+\varepsilon_{f i s t}
\end{aligned}
$$

Although $\theta_{3}$ will still give us the average effect of the interaction of labour intensity and labour reform on productivity, the coefficient $\theta_{7}$ becomes particularly important since it will capture any heterogeneous effects due to differences in $X_{f i s t}$.

In the case of plant size, $X_{\text {fist }}$ will be a matrix of 4 size dummies. These are constructed using number of workers with cutoffs at 50,100, and 250. The first cutoff responds to the presence of a few labour laws that are enforced starting at this establishment size. The second cutoff is consistent 
with IDA's national threshold set in 1982. The last cutoff is in line with empirical evidence for India, above which plant TFP was observed to be substantially higher (Dougherty et al., 2009). This check is particularly important since larger plants are subject to stricter labour regulation but are also more likely to subcontract workers to evade labour laws.

Let the share of contract labour in total expenditures for each plant be given by:

$$
h_{f i s t}^{*}=\delta X_{f i s t}+\nu_{i}+\nu_{s}+\nu_{t}-\mu_{f i s t}
$$

where $\nu_{i}, \nu_{s}$, and $\nu_{t}$ denote industry, state and year fixed effects. From this latent variable, we construct a categorical variable, $h_{f i s t}$, such that $h_{f i s t}=1$ if the plant hires no contract labour, $h_{f i s t}=2$ when the plant spends $20 \%$ or less of their labour costs on indirect labour, and $h_{\text {fist }}=3$ when the plant spends more than $20 \%$ of total labour expenditures on hiring labour through contractors. Let the cutoffs for $h_{\text {fist }}^{*}$ be given by $\xi_{0}=-\infty, \xi_{1}=0, \xi_{2}=0.2$, and $\xi_{3}=\infty$. The probability of $h_{f i s t}=H$ is given by:

$$
\begin{aligned}
\operatorname{Pr}\left(h_{\text {fist }}=H \mid X_{\text {fist }}\right) & =\operatorname{Pr}\left(\xi_{H-1}<h_{\text {fist }}^{*}<\xi_{H} \mid X_{\text {fist }}\right) \\
& =\Phi\left(\delta X_{\text {fist }}+\nu_{i}+\nu_{s}+\nu_{t}-\xi_{H-1}\right)-\Phi\left(\delta X_{f i s t}+\nu_{i}+\nu_{s}+\nu_{t}-\xi_{H}\right)
\end{aligned}
$$

where $\Phi$ is the normal cumulative distribution with mean zero and variance $\sigma^{2}$.

Table 4: Interval regression results for the share of contract labour in total labour expenditures

\begin{tabular}{lcc} 
Plant size (base: $<50$ workers) & $\delta$ & S.E. \\
\hline$[50-100[$ & $0.268^{* * *}$ & 0.004 \\
{$[100-250[$} & $0.300^{* * *}$ & 0.003 \\
250 or more & $0.317^{* * *}$ & 0.003 \\
\hline Observations & 229693 \\
Log likelihood & -165507.27 \\
$\sigma$ & $0.384^{* * *}$ \\
Year FE & yes \\
Industry FE & yes \\
State FE & yes \\
\hline
\end{tabular}

Table 4 reports $\delta$ estimates from an interval regression model like the one above. We find that larger plants are more likely to hire labour indirectly: the share of contracted labour increases by a factor of 0.317 when we compare plants with 250 or more workers to plants with less than 50 workers. Similarly, relative to the smallest plants, medium size plants with 50 to 99 workers and 100 to 249 workers see their share of contract labour expenditures increased by a factor of 0.268 and 0.3 , respectively. Clearly, the tendency of larger plants to hire more workers through contractors helps them partially bypass labour legislation. Consequently, we expect them to benefit less from the state-labour reforms. 
Table 5: Effect of EPL reforms on TFP and labour productivity by labour intensity and plant size, with state-level controls

\begin{tabular}{|c|c|c|}
\hline & $\log (\mathrm{TFP})$ & $\log (\mathrm{VA} / \mathrm{L})$ \\
\hline \multirow[t]{2}{*}{ Constant } & $1.371^{* * *}$ & -0.757 \\
\hline & $(0.261)$ & $(0.995)$ \\
\hline \multirow{2}{*}{ High labour intensity } & -0.049 & $-0.125^{* *}$ \\
\hline & $(0.066)$ & $(0.047)$ \\
\hline \multirow[t]{2}{*}{ Pro-employer EPL reform } & -0.032 & $0.202^{* *}$ \\
\hline & $(0.034)$ & $(0.096)$ \\
\hline \multirow[t]{2}{*}{ High labour intensity x Pro-employer EPL reform } & $0.161^{* *}$ & $0.187^{* * *}$ \\
\hline & $(0.068)$ & $(0.054)$ \\
\hline \multicolumn{3}{|l|}{ Plant Size (Base: $<=50$ workers) } \\
\hline \multirow[t]{2}{*}{] $50-100]$} & 0.127 & 0.069 \\
\hline & $(0.074)$ & $(0.139)$ \\
\hline \multirow{2}{*}{] $100-250]$} & -0.023 & $0.290^{* *}$ \\
\hline & $(0.054)$ & $(0.105)$ \\
\hline \multirow[t]{2}{*}{$>250$} & 0.049 & $0.604^{* * *}$ \\
\hline & $(0.059)$ & $(0.174)$ \\
\hline \multirow[t]{2}{*}{ High labour intensity x ]50-100] } & -0.075 & 0.257 \\
\hline & $(0.096)$ & $(0.178)$ \\
\hline \multirow{2}{*}{ High labour intensity x ]100-250] } & 0.094 & 0.118 \\
\hline & $(0.130)$ & $(0.125)$ \\
\hline \multirow[t]{2}{*}{ High labour intensity $\mathrm{x}>250$} & $0.278^{* * *}$ & -0.133 \\
\hline & $(0.072)$ & $(0.221)$ \\
\hline \multirow{2}{*}{ Pro-employer EPL reform x ]50-100] } & -0.063 & 0.042 \\
\hline & $(0.074)$ & $(0.148)$ \\
\hline \multirow[t]{2}{*}{ Pro-employer EPL reform x ]100-250] } & 0.077 & -0.038 \\
\hline & $(0.059)$ & $(0.156)$ \\
\hline \multirow[t]{2}{*}{ Pro-employer EPL reform $\mathrm{x}>250$} & 0.020 & 0.269 \\
\hline & $(0.064)$ & $(0.175)$ \\
\hline \multirow[t]{2}{*}{ High labour intensity x Pro-employer EPL reform x ]50-100] } & 0.105 & -0.115 \\
\hline & $(0.099)$ & $(0.187)$ \\
\hline \multirow{2}{*}{ High labour intensity x Pro-employer EPL reform x ]100-250] } & -0.034 & -0.130 \\
\hline & $(0.138)$ & $(0.160)$ \\
\hline \multirow[t]{2}{*}{ High labour intensity $x$ Pro-employer EPL reform $x>250$} & $-0.154^{*}$ & $-0.398^{*}$ \\
\hline & $(0.085)$ & $(0.229)$ \\
\hline \multicolumn{3}{|l|}{ Time-variant state controls } \\
\hline \multirow[t]{2}{*}{ Log(Telephones/100 pop) } & $0.044^{* *}$ & 0.033 \\
\hline & $(0.018)$ & $(0.043)$ \\
\hline \multirow[t]{2}{*}{ Log(Installed electricity capacity/million pop) } & -0.028 & -0.018 \\
\hline & $(0.021)$ & $(0.112)$ \\
\hline \multirow[t]{2}{*}{ Log(Paved roads/1000 pop) } & 0.020 & -0.007 \\
\hline & $(0.014)$ & $(0.063)$ \\
\hline \multicolumn{3}{|l|}{ Time-invariant state controls } \\
\hline \multirow[t]{2}{*}{ Product Market Regulation } & -0.026 & 0.089 \\
\hline & $(0.048)$ & $(0.279)$ \\
\hline Observations & 224,634 & 213,147 \\
\hline R-squared & 0.065 & 0.090 \\
\hline Firm trend & yes & yes \\
\hline State-level controls & yes & yes \\
\hline Year FE & yes & yes \\
\hline
\end{tabular}


Table 5 confirms our initial prediction. The coefficient on the interaction between flexible EPL and labour intensity is now positive and significant both for TFP and labour productivity $\left(\theta_{3}\right)$. Moreover, the coefficient on triple interaction between EPL, labour intensity, and plant size $\left(\theta_{7}\right)$ is not significant for medium size plants but it is negative and significant for larger plants in both columns. Both in terms of TFP and labour productivity, plants with more than 250 workers in industries with high labour intensity earn much less than their smaller counterparts from proemployer labour reforms. This result is consistent with the fact that larger plants face higher restrictions in inflexible labour regulation settings. Since many norms and regulations apply only to them, it looks like they have found a way out by reducing their dependence on a permanent workforce and relying more on temporary labour hired through contractors as suggested by Table 4. It has been well documented that casual or contract labour in India provides unskilled labour at wages below the minimum wage and without benefits, so the substitution of regular labour for casual labour can help larger plants reduce the labour costs imposed by more stringent EPL.

We also estimated the effects of flexible EPL separately for publicly and privately owned plants, where $X_{\text {fist }}$ is a dummy that is equal to one when the plant is publicly owned. In the sample periods analyzed, publicly owned plants tend to have lower rates of job destruction and creation than privately owned plants. Although public plants tend to have a lower turnover rate than privately owned plants, their net contribution to employment is highly negative in half of the rounds analyzed. A proposed explanation for this lies in voluntary retirement schemes (VRS), which are used as a mutually agreeable mechanism for downsizing. Since VRS has allowed public plants to bypass labour regulation and adjust their labour usage it may be possible that the effect of EPL within them is smaller than among private plants.

Table 6 presents the results obtained by ownership type. Public plants in labour intensive industries tend to have higher multifactor productivity but lower labour productivity as shown by the interaction of the ownership dummy and the labour intensity dummy. Moreover, the interaction between pro-worker EPL reform and labour intensity is positive and significant for both TFP and VA/L, which shows that the average beneficial effect of labour reform on labour intensive industries is higher. As we expected, the triple interaction for EPL reform, labour intensity, and public ownership is negative and significant for both TFP and labour productivity, though only significant for the former. This implies that labour intensive public plants in flexible markets exhibit lower TFP gains from EPL reform, which is in line with the use of VRS among public plants as a strategy to circumvent labour regulation. Through this strategy, constrained public 
Table 6: Effect of EPL reforms on TFP and labour productivity by labour intensity and ownership type, with state-level controls

\begin{tabular}{lrr} 
& $\log (\mathrm{TFP})$ & $\log (\mathrm{VA} / \mathrm{L})$ \\
\hline Constant & $1.339^{* * *}$ & -0.568 \\
& $(0.279)$ & $(0.910)$ \\
High labour intensity & -0.048 & -0.056 \\
& $(0.051)$ & $(0.064)$ \\
Pro-employer EPL reform & -0.042 & $0.184^{*}$ \\
High labour intensity x Pro-employer EPL reform & $(0.049)$ & $(0.098)$ \\
& $0.213^{* * *}$ & $0.162^{*}$ \\
Public plant & $(0.060)$ & $(0.082)$ \\
& 0.007 & $0.735^{* * *}$ \\
High labour intensity x Public plant & $(0.047)$ & $(0.120)$ \\
& $0.208^{* *}$ & $-0.274^{* *}$ \\
Pro-employer EPL reform x Public plant & $(0.088)$ & $(0.101)$ \\
& 0.069 & 0.203 \\
High labour intensity x Pro-employer EPL reform x Public plant & $(0.051)$ & $(0.135)$ \\
Time-variant state controls & $-0.243^{* *}$ & -0.179 \\
Log(Telephones/100 pop) & $(0.090)$ & $(0.122)$ \\
& & \\
Log(Installed electricity capacity/million pop) & $0.044^{* *}$ & 0.040 \\
Log(Paved roads/1000 pop) & $(0.019)$ & $(0.041)$ \\
Time-invariant state controls & -0.022 & -0.019 \\
Product Market Regulation & $(0.022)$ & $(0.104)$ \\
& 0.016 & -0.004 \\
Observations & $(0.014)$ & $(0.059)$ \\
R-squared & & \\
State-level controls & -0.038 & 0.005 \\
Year FE & $(0.051)$ & $(0.256)$ \\
\hline Sorr & 224,535 & 213,018 \\
& 0.053 & 0.130 \\
& yes & yes \\
& yes & yes \\
& yes & yes \\
\hline
\end{tabular}

Source: Annual Survey of Industries (ASI) 1998-99 to 2007-08.

Robust standard errors in parentheses.

${ }^{* * *} p<0.01,{ }^{* *} p<0.05,{ }^{*} p<0.1$ 
plants have been able to ameliorate the negative effects of inflexible regulation on productivity so that pro-employer labour reforms have smaller relative effects among them.

In general, the results show that there are important TFP and some labour productivity gains for labour intensive plants that operate in states with laxer EPL. Moreover, the different strategies used by plants to overcome the constraints imposed by labour regulation generate differential effects of state-level labour reform both by plant size and type of ownership.

\subsection{Volatility}

We now test if laxer labour regulation benefits volatile industries relatively more as suggested by Poschke (2007) and others. Our measure of volatility is similar to the one used by Krishna and Levchenko (2009): the standard deviation of the annual growth rate of plants' output in a given industry. Notice that we need a plant-level growth measure to quantify volatility, so we are will obtain a proxy for each industry from the restricted census sample, average it over all the ASI rounds we use, and apply it to the complete sample of plants. We then construct a dummy variable which classifies industries as highly volatile when they are at or above the median industry in terms of the average standard deviation of annual growth rate of output.

Panels (a) and (b) in Figure 6 presents preliminary evidence on the existence of a comparative advantage among more volatile plants in flexible markets. State-level labour reforms seem to shift the TFP distribution to the right only in more turbulent industries, which is in line with Cuñat and Melitz's (2007) findings. However, as panels (c) and (d) show, the comparative advantage identified in terms of TFP among plants in more volatile sectors is not present for labour productivity. The difference between the distributions of value added per worker across states with different levels of labour reform does not seem to vary by industry-level volatility, although plants in more flexible states always have better (VA/L) distributions.

Table 7 confirms these patterns. The interaction between EPL and volatility is positive and significant only in the TFP equation, which implies that plants in more volatile industries that operate in flexible labour markets have a comparative advantage in terms of multifactor productivity. The larger costs of hiring and firing people imposed by strict EPL seem to be particularly restrictive in sectors with higher volatility, generating an unequal distribution of the productivity gains that come from labour market deregulation. 
Figure 6: Labour market regulation, volatility, and productivity

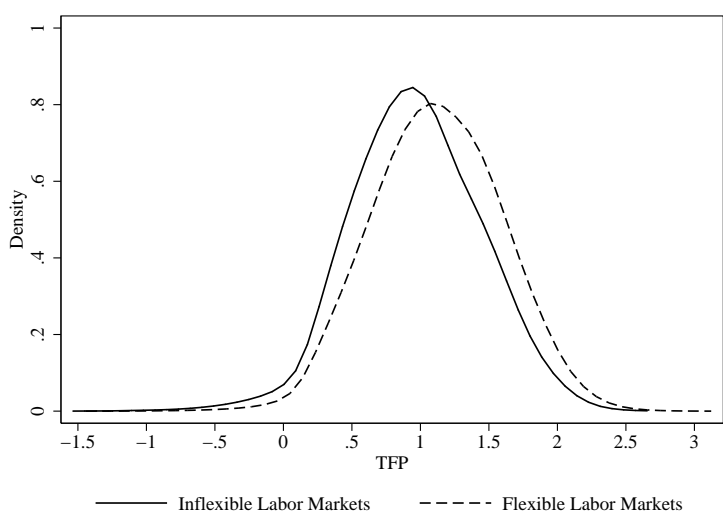

(a) TFP: High volatility

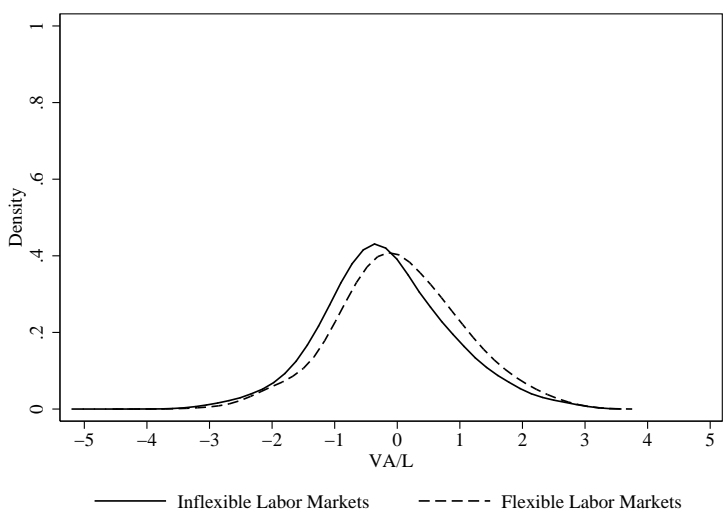

(c) Labour productivity: High volatility

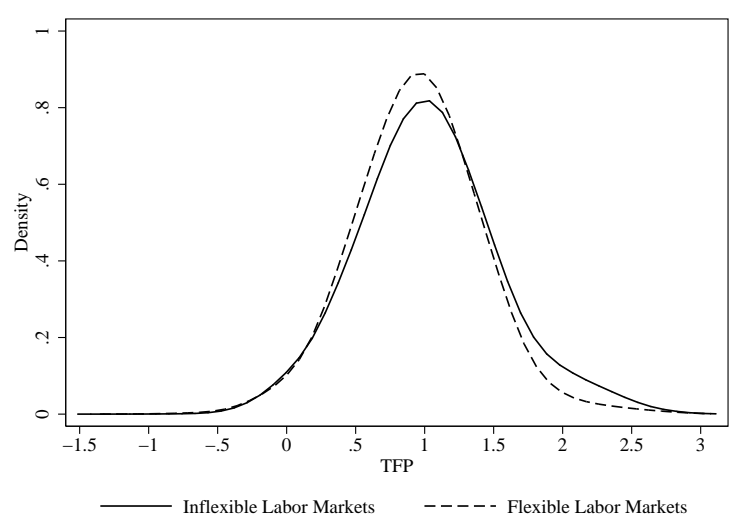

(b) TFP: Low volatility

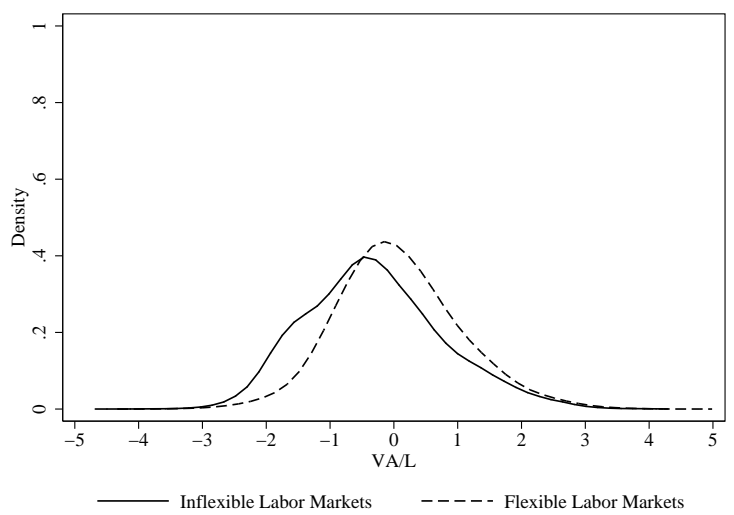

(d) Labour productivity: Low volatility

Source: Annual Survey of Industries (ASI) 1998-99 to 2007-08. 
Table 7: Effect of EPL reforms on TFP and labour productivity by volatility, with state-level controls

\begin{tabular}{|c|c|c|}
\hline & $\log (\mathrm{TFP})$ & $\log (\mathrm{VA} / \mathrm{L})$ \\
\hline \multirow{2}{*}{ Constant } & $1.411^{* * *}$ & -1.078 \\
\hline & $(0.324)$ & $(1.039)$ \\
\hline \multirow{2}{*}{ High volatility } & -0.052 & 0.097 \\
\hline & $(0.108)$ & $(0.097)$ \\
\hline \multirow{2}{*}{ Pro-employer EPL reform } & -0.116 & $0.379^{* * *}$ \\
\hline & $(0.078)$ & $(0.125)$ \\
\hline \multirow{2}{*}{ High volatility x Pro-employer EPL reform } & $0.225^{*}$ & -0.151 \\
\hline & $(0.116)$ & $(0.101)$ \\
\hline \multicolumn{3}{|l|}{ Time-variant state controls } \\
\hline \multirow{2}{*}{ Log(Telephones/100 pop) } & $0.042^{* *}$ & 0.030 \\
\hline & $(0.019)$ & $(0.044)$ \\
\hline \multirow[t]{2}{*}{ Log(Installed electricity capacity/million pop) } & -0.020 & 0.018 \\
\hline & $(0.022)$ & $(0.114)$ \\
\hline \multirow[t]{2}{*}{ Log(Paved roads/1000 pop) } & 0.016 & -0.027 \\
\hline & $(0.015)$ & $(0.065)$ \\
\hline \multicolumn{3}{|l|}{ Time-invariant state controls } \\
\hline \multirow[t]{2}{*}{ Product Market Regulation } & -0.058 & 0.041 \\
\hline & $(0.057)$ & $(0.283)$ \\
\hline Observations & 224,634 & 213,147 \\
\hline R-squared & 0.051 & 0.044 \\
\hline Firm trend & yes & yes \\
\hline State-level controls & yes & yes \\
\hline Year FE & yes & yes \\
\hline
\end{tabular}

\section{Robustness Checks}

In the previous section, we showed that plants in more labour intensive and/or more volatile industries are the big winners of pro-worker labour reforms in India. The interactions between higher levels of EPL reform and labour intensity as well as between pro-worker EPL reform and volatility were positive and significant even after the introduction of state-level controls. Moreover, Tables B.3 and B.4 in Appendix B show that our results are not sensitive to a different specification of the labour intensity measure. Including labour intensity in the model either as the value of $\hat{\alpha}$ or the relative ranking of each industry implied by $\hat{\alpha}$ does not affect the results presented above.

This section provides additional robustness tests of the impact of labour regulation on organized manufacturing plants. First, we try out two alternative measures of EPL available in the literature. We use Gupta et al.'s (2009) EPL index as well as the BB index updated through 2008 using Malik (2010). The former uses the BB index, Bhattacharjea (2006)'s indicator — which takes into account legislative and judicial interventions affecting Chapter VB of the IDA - and Dougherty's (2009) 
index to construct a composite measure of labour regulation. This composite measure, which we call EPL-G, classifies states into inflexible, neutral, and flexible in terms of their EPL strictness.

We also check if our results hold when we use industry layoff propensity instead of labour intensity. According to Bassanini et al. (2009), the firm's natural propensity to adjust through layoffs will influence the size of the costs imposed by EPL so we would expect that plants that operate in industries that are more likely to adjust through layoffs will benefit the most from more flexible labour laws, especially those pertaining to retrenchment and firing of workers.

Table 8 shows the results using Gupta et al.'s (2009) EPL indicator 21 If we focus on the interaction effect identified for states classified as flexible by EPL-G, the results are very similar to those obtained with our measure of EPL reform. In terms of TFP gains, Table 3 reported an interaction effect of 0.153 while this effect amounts to 0.143 when EPL-G is used. Although still insignificant, the interaction effect of EPL-G and labour intensity in the labour productivity equation (0.120) is very close to the effect identified in Table 3 using our EPL measure (0.124).

When the BB index is used, the positive effects of labour regulation previously identified among plants in labour intensive industries go away. Table 9 shows that when the cumulative BB index is used, the interaction between EPL reform and labour intensity is negative and significant in the case of TFP though it remains insignificant for value added per worker. These results are not too surprising if we consider that the BB index only captures formal amendments to the IDA, which have been scarce in recent years. In fact, there were only four pro-worker reforms registered in Gujarat (in 2004) and two pro-employer reforms in Madhya Pradesh (in 2003) after 1999. Moreover, the correlation between BB and Dougherty's (2009) proportional index is -0.25 , which could be indicating that the lack of reforms to the IDA post-1990 were compensated by formal or informal state-level changes in industrial practices on the ground.

We conclude by testing if plants in industries with a higher layoff propensity benefit the most from labour reforms as suggested by Bassanini et al. (2009) 22 The evidence provided in Table 10 shows that, indeed, plants in industries with higher $\hat{\alpha}$ s are the ones who experience the largest TFP improvements from state-level labour reforms. The magnitude of the interaction effect of EPL reforms and layoff propensities implies that, on average, plants in industries with a high layoff propensity are $20 \%$ more productive in flexible states than in inflexible states.

\footnotetext{
${ }^{21}$ Compared to our final sample of states, Gupta et al. (2009) misses 2 states/union territories, Delhi and Himachal Pradesh, which represent $6.2 \%$ of the plant-year observations in our complete sample.

${ }^{22}$ Due to lack of adequate US data, tobacco industries were dropped from our original sample. This generates a loss of $1.35 \%$ of the plant-year observations.
} 
Table 8: Effect of EPL-G on productivity and output by labour intensity, all plants

\begin{tabular}{lrr} 
& $\log (\mathrm{TFP})$ & $\log (\mathrm{VA} / \mathrm{L})$ \\
\hline Constant & $1.059^{* *}$ & -0.085 \\
High labour intensity & $(0.380)$ & $(1.657)$ \\
& $0.055^{* * *}$ & $-0.104^{* * *}$ \\
Neutral EPL-G & $(0.007)$ & $(0.026)$ \\
& 0.006 & -0.293 \\
Flexible EPL-G & $(0.025)$ & $(0.177)$ \\
& -0.027 & -0.269 \\
High LI x Neutral EPL-G & $(0.025)$ & $(0.166)$ \\
& 0.052 & 0.144 \\
High LI x Flexible EPL-G & $(0.036)$ & $(0.089)$ \\
& $0.143^{* * *}$ & 0.120 \\
Time-variant state controls & $(0.042)$ & $(0.086)$ \\
Log(Telephones/100 pop) & & \\
& 0.038 & 0.082 \\
Log(Installed electricity capacity/million pop) & $(0.024)$ & $(0.078)$ \\
& 0.005 & 0.003 \\
Log(Paved roads $/ 1000$ pop) & $(0.030)$ & $(0.119)$ \\
& 0.001 & -0.034 \\
Time-invariant state controls & $(0.018)$ & $(0.064)$ \\
Product Market Regulation & & \\
& -0.065 & -0.215 \\
Observations & $(0.050)$ & $(0.329)$ \\
R-squared & 215,208 & 204,129 \\
Firm trend & 0.047 & 0.045 \\
State-level controls & yes & yes \\
Year FE & yes & yes \\
\hline Source: Annual Survey of Industries (ASI) $1998-99$ to $2007-08$. & yes \\
Robust standard errors in parentheses. & & \\
${ }^{* * *} p<0.01,{ }^{* *} p<0.05,{ }^{*} p<0.1$ & &
\end{tabular}

\section{Conclusions and Extensions}

This paper studies the extent to which the effects of EPL on productivity among registered manufacturing plants change by labour intensity. To do this, we rely on a difference-in-differences strategy that includes state-level EPL reforms and industry-level labour intensity interactions. Our main finding is that there are important positive gains in terms of multifactor productivity for labour intensive plants that operate in states with laxer labour regulation. This effect remains after the addition of state-level controls as well as various sensitivity checks. Our point estimates indicate that, on average, plants in labour intensive industries and in flexible labour markets have TFP residuals $14 \%$ higher than those registered for their counterparts in states with more stringent labour laws. However, EPL reform does not seem to have any important effect on plants with lower levels of labour intensity. Similarly, the TFP of plants in more volatile industries and in states that 
$\operatorname{ECO} / \mathrm{WKP}(2011) 86$

Table 9: Effect of EPL measured by BB index on productivity and output by labour intensity, all plants

\begin{tabular}{|c|c|c|}
\hline & $\log (\mathrm{TFP})$ & $\log (\mathrm{VA} / \mathrm{L})$ \\
\hline Constant & $\begin{array}{r}1.173^{* * *} \\
(0.326)\end{array}$ & $\begin{array}{r}0.100 \\
(1.320)\end{array}$ \\
\hline High labour intensity & $\begin{array}{r}0.193^{\text {*** }} \\
(0.050)\end{array}$ & $\begin{array}{l}-0.005 \\
(0.115)\end{array}$ \\
\hline Neutral EPL (BB) & $\begin{array}{r}0.011 \\
(0.031)\end{array}$ & $\begin{array}{r}0.080 \\
(0.152)\end{array}$ \\
\hline Flexible EPL (BB) & $\begin{array}{r}0.022 \\
(0.029)\end{array}$ & $\begin{array}{c}0.338^{*} \\
(0.170)\end{array}$ \\
\hline High labour intensity x Neutral EPL (BB) & $\begin{array}{r}-0.063 \\
(0.055)\end{array}$ & $\begin{array}{r}0.059 \\
(0.130)\end{array}$ \\
\hline High labour intensity x Flexible EPL (BB) & $\begin{array}{r}-0.137^{* *} \\
(0.051)\end{array}$ & $\begin{array}{r}-0.098 \\
(0.116)\end{array}$ \\
\hline Time-variant state controls & & \\
\hline Log(Telephones/100 pop) & $\begin{array}{r}0.040^{* *} \\
(0.018)\end{array}$ & $\begin{array}{r}0.093 \\
(0.067)\end{array}$ \\
\hline Log(Installed electricity capacity/million pop) & $\begin{array}{r}-0.008 \\
(0.028)\end{array}$ & $\begin{array}{r}-0.037 \\
(0.101)\end{array}$ \\
\hline Log(Paved roads/1000 pop) & $\begin{array}{r}0.007 \\
(0.017)\end{array}$ & $\begin{array}{r}-0.010 \\
(0.050)\end{array}$ \\
\hline Time-invariant state controls & & \\
\hline Product Market Regulation & $\begin{array}{r}-0.061 \\
(0.047) \\
\end{array}$ & $\begin{array}{r}-0.226 \\
(0.282)\end{array}$ \\
\hline Observations & 224,634 & 213,147 \\
\hline R-squared & 0.048 & 0.046 \\
\hline Firm trend & yes & yes \\
\hline State-level controls & yes & yes \\
\hline Year FE & yes & yes \\
\hline
\end{tabular}

experienced pro-employer reforms is $11 \%$ higher than that of plants in volatile industries and in more restrictive states. Among plants in less volatile industries, EPL reform seems to drive a $11 \%$ reduction in TFP residuals. In the case of labour productivity, we fail to find robust evidence in favor of a differential effect of EPL reform by either labour intensity or volatility.

We also find that the different strategies used by plants to overcome the constraints imposed by labour regulations generate heterogeneous effects of state-level labour reform both by plant size and type of ownership. Given the extensive use of contract labour among large plants and voluntary retirement schemes among public plants, smaller plants and private plants tend to accrue the largest productivity gains from state-level labour reforms.

Our study is particularly important for three reasons. This is the first study that makes use of plant-level information from the ASI to evaluate the effect of EPL in India. Second, we take 
Table 10: Effect of EPL on productivity and output by layoff propensity, all plants

\begin{tabular}{|c|c|c|}
\hline & $\log (\mathrm{TFP})$ & $\log (\mathrm{VA} / \mathrm{L})$ \\
\hline \multirow{2}{*}{ Constant } & $1.169^{* * *}$ & -1.023 \\
\hline & $(0.259)$ & $(1.001)$ \\
\hline \multirow[t]{2}{*}{ High layoff propensity } & 0.080 & $-0.179^{* *}$ \\
\hline & $(0.065)$ & $(0.082)$ \\
\hline \multirow{2}{*}{ Flexible EPL } & -0.027 & $0.251^{* * *}$ \\
\hline & $(0.042)$ & $(0.087)$ \\
\hline \multirow[t]{2}{*}{ High layoff propensity x Flexible EPL } & $0.213^{* * *}$ & $0.179 *$ \\
\hline & $(0.071)$ & $(0.096)$ \\
\hline \multicolumn{3}{|l|}{ Time-variant state controls } \\
\hline \multirow[t]{2}{*}{ Log(Telephones/100 pop) } & $0.041^{*}$ & 0.033 \\
\hline & $(0.020)$ & $(0.044)$ \\
\hline \multirow[t]{2}{*}{ Log(Installed electricity capacity/million pop) } & -0.013 & 0.018 \\
\hline & $(0.019)$ & $(0.114)$ \\
\hline \multirow[t]{2}{*}{ Log(Paved roads/1000 pop) } & 0.009 & -0.026 \\
\hline & $(0.013)$ & $(0.065)$ \\
\hline \multicolumn{3}{|l|}{ Time-invariant state controls } \\
\hline \multirow[t]{2}{*}{ Product Market Regulation } & -0.028 & 0.065 \\
\hline & $(0.045)$ & $(0.289)$ \\
\hline Observations & 224,634 & 213,147 \\
\hline R-squared & 0.104 & 0.044 \\
\hline Firm trend & yes & yes \\
\hline State-level controls & yes & yes \\
\hline Year FE & yes & yes \\
\hline
\end{tabular}

advantage of the recently available ASI panel data to obtain plant-level TFP measures that control for simultaneity and selection bias using the Olley-Pakes approach. This feature is unique to our study since previous papers on the topic have only measured the effects of EPL on labour productivity measured as value added per worker or on aggregate measures of TFP at the industrylevel. Finally, our measure of labour regulation is much more comprehensive and appropriate for the years analyzed than the BB index, popular in the EPL literature in India. In particular, our EPL reform index takes into account both formal and informal amendments to the labour laws at the state level.

Although the coverage of our EPL reform indicator is a plus, we acknowledge the important data limitations posed by the OECD index. Our analysis could greatly benefit from a time series version of the labour reform indicator that could allow us to evaluate short versus long-term effects as well as to include fixed effects at the state level. However, our attempts to collect a time-varying statelevel EPL indicator have not yet been successful. Since the index goes beyond formal amendments to cover informal changes to labour rules and practices, many of which are not systematically 
$\operatorname{ECO} / \mathrm{WKP}(2011) 86$

notified in a consolidated publication, it is very difficult to track the exact dates in which these practices actually changed at the state level.

Although we are able to take advantage of the longitudinal data available in the ASI, we are aware that assuming that the production function estimates from the restricted census sample are applicable to the complete sample is a little extreme. Unfortunately, this is the only way in which we can implement the Olley-Pakes methodology to obtain clean estimates of plant-level TFP residuals. We believe that relying on OLS estimates of multifactor productivity in the complete sample would be even more problematic than the approach we undertake here.

Preliminary evidence shows that the effect of labour regulation reforms might be non-linear, which could potentially be explained by endogenous relocation of plants from states with more stringent regulation to states with more flexible EPL. Our future agenda includes the development of a partial equilibrium model that can help us explain this pattern. 
$\operatorname{ECO} / \mathrm{WKP}(2011) 86$

\section{References}

[1] Aghion, Philippe, Robin Burgess, Stephen J. Redding, and Fabrizio Zilibotti (2008), "The Unequal Effects of Liberalization: Evidence from Dismantling the License Raj in India", American Economic Review, 98(4): 1397-1412.

[2] Ahsan, Ahmad and Carmen Pagés (2009), "Are all labour Regulations Equal? Evidence from Indian Manufacturing", Journal of Comparative Economics, 37(1): 62-75.

[3] Arnold, Jens Mathias (2005), "A short note on Productivity Estimation at the Firm Level. A Practical Guide". Working paper, Bocconi University.

[4] Adhvaryu, Achyuta, Amalavoyal Chari, and Siddharth Sharma (2011), "Firing Costs and Flexibility: Evidence from Firms' Labor Adjustments to Shocks in India", Working Paper.

[5] Bassanini, Andrea, Luca Nunziata, and Danielle Venn (2009), "Job protection legislation and productivity growth in OECD countries", Economic Policy, CEPR, CES, MSH, 24: 349-402.

[6] Basu, Susanto and John G. Fernald (1997), "Returns to Scale in U.S. Production: Estimates and Implications", Journal of Political Economy, 105(2): 249-283.

[7] Bentolila, S. and Bertola, G. (1990), "Firing Costs and labour Demand: How Bad is Eurosclerosis?", Review of Economic Studies, Vol. 57: 381-402.

[8] Besley, Timothy and Robin Burgess (2004), "Can labour regulation hinder economic performance? Evidence from India", The Quarterly Journal of Economics, 119(1): 91-134.

[9] Bhattacharjea, Aditya (2006), "labour Market Regulation and Industrial Performance in India: A Critical Review of the Empirical Evidence", The Indian Journal of labour Economics, 49(2): $211-32$.

[10] (2009), "The Effects of Employment Protection Legislation on Indian Manufacturing", Working paper, Center on Democracy, Development, and The Rule of Law Freeman Spogli Institute for International Studies, Stanford University.

[11] Bollard, Albert, Peter J. Klenow, and Gunjan Sharma (2010), "India's Mysterious Manufacturing Miracle", Stanford University, Manuscript.

[12] Carlsson, Mikael, Julián Messina and Oskar Nordström Skans (2011), "Wage Adjustment and Productivity Shocks", IZA Working Paper No. 5719.

[13] Conway, Paul and Richard Herd (2009), "How Competitive is Product Market Regulation in India? An International and Cross-state Comparison", OECD Economic Studies, 45(1): 149-174.

[14] Cuñat, Alejandro and Marc Melitz (2007), "Volatility, labour Market Flexibility, and the Pattern of Comparative Advantage", NBER Working Paper No. 13062.

[15] Deakin, Simon, Priya Lele, and Mathias Siems (2007), "The evolution of labour law: calibrating and comparing regulatory regimes", International labour Review, 146:133-162.

[16] Dougherty, Sean (2009), "Labour Regulation and Employment Dynamics at the State Level in India", Review of Market Integration, 1(3): 295-337. 
[17] Dougherty, Sean, Richard Herd and Thomas Chalaux (2009), "What is Holding Back Productivity Growth in India? Recent Microevidence", OECD Economic Studies, 45(1): 59-80.

[18] Garibaldi, Pietro (1998), "Job flow dynamics and firing restrictions", European Economic Review, 42(2): 245-75.

[19] Goldar, Bishwanath and Suresh Chand Aggarwa (2010), "Informalization of Industrial labour in India: Are labour market rigidities and growing import competition to blame?", Institute for Economic Growth, New Delhi, Manuscript.

[20] Goldar, Bishwanath (2011), "Growth in Organised Manufacturing Employment in Recent Years", Economic and Political Weekly, Vol. XLVI, No. 5.

[21] Gupta, Poonam, Rana Hasan, and Utsav Kumar (2009), "Big Reforms but Small Payoffs: Explaining the Weak Record of Growth in Indian Manufacturing", MPRA Working Paper, University Library of Munich, Germany.

[22] Harrison, Ann, Leslie Martin, and Shanthi Nataraj (2011), "Learning versus Stealing: How Important are Market-Share Reallocations to India's Productivity Growth?", NBER Working Paper No. 16733.

[23] Krishna, Pravin and Andrei Levchenko (2009), "Comparative Advantage, Complexity, and Volatility", NBER Working Paper No. 14965.

[24] Levinsohn, James and Amil Petrin (2003), "Estimating Production Functions using Inputs to Control for Unobservables", Review of Economic Studies, 70: 317-341.

[25] Malik, P.L. (2006, 2010), Industrial Law: A Manual of Central labour and Industrial Laws Incorporating State Amendments with Rules, Regulations and Select Notifications, Lucknow: Eastern Book Company.

[26] Micco, Alejandro and Carmen Pagés (2007), "The Economic Effects of Employment Protection: Evidence from International Industry-Level Data". Research Network Working Papers 592, Inter-American Development Bank, Research Department.

[27] Ministry of Commerce and Industry (2011), Annual Report 2010-2011, New Delhi.

[28] Mortensen, D.T. and C.A. Pissarides (1999), "Unemployment responses to 'skill biased' shocks: the role of labour market policy", Economic Journal, 109: 242-65.

[29] Nagaraj, R. (2004), "Fall in Organised Manufacturing Employment: A Brief Note", Economic and Political Weekly, 39(30): 3387-90.

[30] OECD (2007, 2011), OECD Economic Surveys of India, Paris: OECD Publishing.

[31] Olley, Steven and Ariel Pakes (1996), "The Dynamics Of Productivity In The Telecommunications Equipment Industry", Econometrica, 64: 1263-1297.

[32] Panagariya, Arvind (2008), India: the Emerging Giant, New York: Oxford University Press.

[33] Poschke, M. (2009), "Employment protection, firm selection, and growth", Journal of Monetary Economics, 56(8): 1074-85. 
[34] Rajan, Raghuram and Luigi Zingales (1998), "Financial dependence and growth", American Economic Review, 88: 559-86.

[35] Venn, Danielle (2009), "Legislation, collective bargaining and enforcement: Updating the OECD employment protection indicators", OECD Social, Employment and Migration Working Paper 89.

[36] World Trade Organization (2010), International Trade Statistics 2010, Geneva. 


\section{A Appendix A: Construction of Price Deflators}

Output and value added were deflated by the appropriate wholesale price index (WPI) by industry groups and subgroups with base 1993-94. Although the detailed categories for which the WPI data is available do not exactly match the 2-digit industry classification of the ASI, a close and detailed comparison of the groups was undertaken to select suitable price deflators. Fixed capital, investment, and invested capital were deflated using the WPI for machinery and equipment while real expenditures in fuels were obtained using the WPI for fuel, power lights, and lubricants, both with base 1993-94. To deflate intermediate materials, several deflators were used. For each factory, the ASI gives detailed quantity and expenditure data on all intermediate goods consumed for five broad groups: basic materials (including imports), chemicals and auxiliary materials, packing materials, consumable stores, and materials consumed for repair and maintenance. Basic inputs and imports are identified by 5 -digit ASICC codes. Consumption of basic materials was deflated using the WPI for the category that best matched 2-digit ASICC codes with base 1993-94. Imports were deflated using the Unit Value Index (UVI) for imports with base 1993-94 that best matched 2-digit ASICC codes. For chemicals and auxiliary materials the WPI of chemicals and chemical products is used. For packing materials, a weighed average of the WPI for paper products, wood and wood products, and jute, hemp, and mesta textiles is obtained. Consumable stores are deflated using a weighted average of WPI for wood and wood products, basic metals alloys and metal products, and chemicals and chemical products. Materials consumed for repair and maintenance are deflated using WPI for machinery and machine tools. 


\section{B Appendix B: Additional Tables}

Table B.1: Descriptive Statistics: All years

(a) All plants

\begin{tabular}{|c|c|c|c|c|c|}
\hline Variable & Obs & Mean & S.D & Min & Max \\
\hline Output & 239921 & 330.24 & 3075.47 & 0.01 & 320327.70 \\
\hline Value added & 239921 & 38.47 & 213.83 & -157.29 & 26969.15 \\
\hline Fixed capital & 239921 & 111.22 & 722.22 & 0.00 & 56809.98 \\
\hline Number of workers & 239921 & 175.76 & 420.85 & 0.00 & 21637.00 \\
\hline Investment & 239921 & 14.87 & 128.99 & 0.00 & 17713.72 \\
\hline Fuel expenditures & 239921 & 7.32 & 39.16 & 0.00 & 2639.63 \\
\hline Intermediate inputs & 239921 & 136.33 & 878.74 & 0.00 & 66449.92 \\
\hline Share of contract labour & 239726 & 0.09 & 0.20 & 0.00 & 1.00 \\
\hline Age of the plant & 239088 & 20.92 & 19.61 & 0.00 & 208.00 \\
\hline \multicolumn{6}{|l|}{ Plant size dummies (based on $\sharp$ workers) } \\
\hline$<50$ & 239921 & 0.52 & & 0.00 & 1.00 \\
\hline$[50-100[$ & 239921 & 0.13 & & 0.00 & 1.00 \\
\hline$[100-250[$ & 239921 & 0.16 & & 0.00 & 1.00 \\
\hline$\geq 250$ & 239921 & 0.18 & & 0.00 & 1.00 \\
\hline $\bar{P}$ ublic ownership (dummy) & 239785 & 0.23 & & 0.00 & 1.00 \\
\hline TFP (Olley-Pakes residuals) & 238961 & 1.05 & 0.47 & -6.96 & 5.29 \\
\hline Labour productivity (VA/L) & 222363 & 0.00 & 1.02 & -5.00 & 4.79 \\
\hline Volatility (S.D. of annual growth rate of output) & 239921 & 0.71 & 0.20 & 0.31 & 0.98 \\
\hline \multicolumn{6}{|c|}{ (b) Restricted Census sample } \\
\hline Variable & Obs & Mean & S.D & Min & Max \\
\hline Output & 49895 & 1290.73 & 6642.43 & 0.02 & 320327.70 \\
\hline Value added & 49895 & 154.63 & 446.22 & -157.29 & 26969.15 \\
\hline Fixed capital & 49895 & 455.01 & 1518.57 & 0.00 & 56809.98 \\
\hline Number of workers & 49895 & 646.61 & 745.19 & 200.00 & 21637.00 \\
\hline Investment & 49895 & 58.33 & 267.54 & 0.00 & 17713.72 \\
\hline Fuel expenditures & 49895 & 29.34 & 81.24 & 0.00 & 2639.63 \\
\hline Intermediate inputs & 49895 & 513.08 & 1868.66 & 0.14 & 66449.92 \\
\hline Share of contract labour & 49873 & 0.10 & 0.18 & 0.00 & 1.00 \\
\hline Age of the plant & 49880 & 28.88 & 25.34 & 0.00 & 208.00 \\
\hline \multicolumn{6}{|l|}{ Plant size dummies (based on $\sharp$ workers) } \\
\hline$<50$ & 49895 & 0.00 & & 0.00 & 0.00 \\
\hline$[50-100[$ & 49895 & 0.00 & & 0.00 & 0.00 \\
\hline$[100-250[$ & 49895 & 0.15 & & 0.00 & 1.00 \\
\hline$\geq 250$ & 49895 & 0.85 & & 0.00 & 1.00 \\
\hline$\overline{\text { Public ownership dummy }}$ & 49864 & 0.59 & & 0.00 & 1.00 \\
\hline TFP (Olley-Pakes residuals) & 49879 & 1.10 & 0.49 & -6.96 & 4.04 \\
\hline Labour productivity (VA/L) & 46204 & 0.44 & 1.10 & -4.14 & 4.79 \\
\hline Volatility (S.D. of annual growth rate of output) & 49895 & 0.72 & 0.19 & 0.31 & 0.98 \\
\hline
\end{tabular}


$\operatorname{ECO} / \mathrm{WKP}(2011) 86$

Table B.2: Effect of EPL reforms on total output and total value added by labour intensity, adding state-level controls

\begin{tabular}{lrr} 
& $\log (\mathrm{Q})$ & $\log (\mathrm{VA})$ \\
\hline Constant & $-3.564^{* *}$ & $-4.325^{* * *}$ \\
High labour intensity & $(1.614)$ & $(1.470)$ \\
& -0.149 & -0.152 \\
Flexible EPL & $(0.161)$ & $(0.115)$ \\
& $0.253^{*}$ & $0.390^{* * *}$ \\
High labour intensity x Flexible EPL & $(0.139)$ & $(0.128)$ \\
& 0.184 & 0.190 \\
Time-variant state controls & $(0.165)$ & $(0.120)$ \\
Log(Telephones/100 pop) & & \\
& -0.007 & -0.018 \\
Log(Installed electricity capacity/million pop) & $(0.101)$ & $(0.081)$ \\
& 0.228 & 0.237 \\
Log(Paved roads/1000 pop) & $(0.170)$ & $(0.145)$ \\
& -0.149 & $-0.147^{*}$ \\
Time-invariant state controls & $(0.098)$ & $(0.084)$ \\
Product Market Regulation & & \\
& -0.149 & 0.136 \\
Observations & $(0.433)$ & $(0.419)$ \\
R-squared & 217,379 & 229,863 \\
Firm trend & 0.196 & 0.179 \\
State-level controls & yes & yes \\
Year FE & yes & yes \\
\hline
\end{tabular}

Source: Annual Survey of Industries (ASI) 1998-99 to 2007-08.

Robust standard errors in parentheses.

Note: Output $(\mathrm{Q})$ and value added (VA) are net of industry fixed effects.

${ }^{* * *} p<0.01,{ }^{* *} p<0.05,{ }^{*} p<0.1$ 
$\mathrm{ECO} / \mathrm{WKP}(2011) 86$

Table B.3: Effect of EPL reforms on TFP and VA/L by labour intensity, adding state-level controls $\left(L I_{i}\right.$ as the value of $\left.\hat{\alpha}\right)$

\begin{tabular}{lrr} 
& $\log (\mathrm{TFP})$ & $\log (\mathrm{VA} / \mathrm{L})$ \\
\hline Constant & $1.432^{* * *}$ & -0.998 \\
& $(0.332)$ & $(1.011)$ \\
Labour intensity $(\hat{\alpha})$ & -0.067 & $0.242^{* *}$ \\
& $(0.047)$ & $(0.092)$ \\
Flexible EPL & $-1.681^{* * *}$ & $-0.499^{*}$ \\
& $(0.345)$ & $(0.278)$ \\
Labour intensity $(\hat{\alpha})$ x Flexible EPL & $1.485^{* * *}$ & 0.638 \\
& $(0.425)$ & $(0.431)$ \\
Time-variant state controls & & \\
Log(Telephones/100 pop) & $0.055^{* * *}$ & 0.029 \\
& $(0.017)$ & $(0.044)$ \\
Log(Installed electricity capacity/million pop) & -0.014 & 0.016 \\
& $(0.025)$ & $(0.115)$ \\
Log(Paved roads/1000 pop) & 0.015 & -0.026 \\
& $(0.015)$ & $(0.065)$ \\
Time-invariant state controls & & \\
Product Market Regulation & -0.052 & 0.055 \\
& $(0.060)$ & $(0.289)$ \\
\hline Observations & 224,634 & 213,147 \\
R-squared & 0.031 & 0.043 \\
Firm trend & yes & yes \\
State-level controls & yes & yes \\
Year FE & yes & yes \\
\hline
\end{tabular}

Source: Annual Survey of Industries (ASI) 1998-99 to 2007-08.

Robust standard errors in parentheses.

${ }^{* * *} p<0.01,{ }^{* *} p<0.05,{ }^{*} p<0.1$ 
ECO/WKP(2011)86

Table B.4: Effect of EPL reforms on TFP and VA/L by labour intensity, adding state-level controls $\left(L I_{i}\right.$ as a ranking based on $\left.\hat{\alpha}\right)$

\begin{tabular}{lrr} 
& $\log (\mathrm{TFP})$ & $\log (\mathrm{VA} / \mathrm{L})$ \\
\hline Constant & $1.282^{* * *}$ & -0.992 \\
& $(0.283)$ & $(1.010)$ \\
Labour intensity (ranking) & -0.114 & $0.235^{* *}$ \\
& $(0.068)$ & $(0.111)$ \\
Flexible EPL & -0.003 & -0.006 \\
& $(0.006)$ & $(0.006)$ \\
Labour intensity (ranking) x Flexible EPL & $0.016^{* *}$ & 0.006 \\
& $(0.007)$ & $(0.007)$ \\
Time-variant state controls & & \\
Log(Telephones/100 pop) & $0.043^{* *}$ & 0.030 \\
& $(0.019)$ & $(0.045)$ \\
Log(Installed electricity capacity/million pop) & -0.017 & 0.018 \\
& $(0.022)$ & $(0.116)$ \\
Log(Paved roads/1000 pop) & 0.014 & -0.026 \\
& $(0.014)$ & $(0.065)$ \\
Time-invariant state controls & & \\
Product Market Regulation & -0.030 & 0.056 \\
& $(0.050)$ & $(0.290)$ \\
\hline Observations & 224,634 & 213,147 \\
R-squared & 0.045 & 0.043 \\
Firm trend & yes & yes \\
State-level controls & yes & yes \\
Year FE & yes & yes \\
\hline
\end{tabular}

Source: Annual Survey of Industries (ASI) 1998-99 to 2007-08.

Robust standard errors in parentheses.

${ }^{* * *} p<0.01,{ }^{* *} p<0.05,{ }^{*} p<0.1$ 


\section{WORKING PAPERS}

The full series of Economics Department Working Papers can be consulted at www.oecd.org/eco/workingpapers/

916. Systemically important banks and capital regulation challenge

(December 2011) by Patrick Slovik

915. Improving educational outcomes in Slovenia

(December 2011) by Mehmet Eris

914. Addressing challenges in the energy sector in Israel

(December 2011) by Philip Hemmings

913. Issues in private sector finance in Israel

(December 2011) by Philip Hemmings

912. How to improve the economic policy framework for the housing market in Israel

(December 2011) by Philip Hemmings

911. Fiscal Prospects and Reforms in India

(December 2011) by Richard Herd, Sam Hill and Vincent Koen

910. Structural reforms to reduce unemployment and restore competitiveness in Ireland

(December 2011) by Álvaro Pina

909. Getting back on track: restoring fiscal sustainability in Ireland

(December 2011) by David Haugh

908. A welfare analysis of climate change mitigation policies

(November 2011) by Alain de Serres and Fabrice Murtin

907. Overcoming the banking crisis in Ireland

(November 2011) by Muge Adalet McGowan

906. Macroeconomic and structural policies to further stabilise the Mexican economy

(November 2011) by Cyrille Schwellnus

905. Reaping the benefits of a transition to greener growth in Slovakia

(November 2011) by Caroline Klein

$904 \quad$ Fiscal reform for a stronger fairer and cleaner Mexican economy

(October 2011) by Nicola Brandt and Rodrigo Paillacar

903 The demand for safe assets in emerging economies and global unbalances: new empirical evidence (October 2011) by Rudiger Ahrend and Cyrille Schwellnus

902. Drivers of systemic banking crises: the role of bank-balance-sheet contagion and financial account structure

(October 2011) by Rudiger Ahrend and Antoine Goujard 
901 Explaining the appreciation of the Brazilian Real

(October 2011) by Annabelle Mourougane

$900 \quad$ Raising investment in Brazil

(October 2011) by Jens Arnold

899 Refining macroeconomic policies to sustain growth in Brazil

(October 2011) by Annabelle Mourougane

898. Promoting infrastructure development in Brazil

(October 2011) by Annabelle Mourougane and Mauro Pisu

897. Austria: public sector inefficiencies have become less affordable

(October 2011) by Karin Fischer, Rauf Gönenç and Robert Price

896. Informality in Mexico

(September 2011) by Nicola Brandt

895. Reforming Austria's highly regarded but costly health system

(September 2011) by Rauf Gönenç, Maria. M. Hofmarcher, Andreas Wörgötter

894 Greener growth in the Belgian federation

(September 2011) by Tomasz Koźluk

893. Green growth and climate change policies in New Zealand

(September 2011) by Alexandra Bibbee

892. Has deregulation increased investment in infrastructure? Firm-level evidence from OECD countries

(September 2011) by Sónia Araújo

891. Ensuring a Sustainable and Efficient Fishery in Iceland

(September 2011) by Gunnar Haraldsson and David Carey

890. Japan's New Growth Strategy to create demand and Jobs

(September 2011) by Randall S. Jones and Byungseo Yoo

889. Labour market reforms in Japan to improve growth and equity

(September 2011) by Randall S. Jones and Satoshi Urasawa

888. Education reform in Japan

(September 2011) by Randall S. Jones

887. The Political Economy of Climate Change Mitigation Policies: How to Build a Constituency to Address Global Warming?

(August 2011) by Alain de Serres, John Llewellyn and Preston Llewellyn

886. Climate-Change Policy in the United Kingdom

(August 2011) by Alex Bowen and James Rydge 